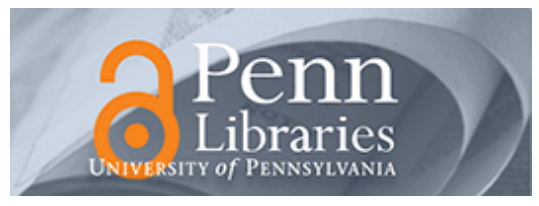

University of Pennsylvania

ScholarlyCommons

Accounting Papers

Wharton Faculty Research

$12-15-2013$

\title{
Mandatory IFRS Reporting and Changes in Enforcement
}

Hans B. Christensen

Luzi Hail

University of Pennsylvania

Christian Leuz

Follow this and additional works at: https://repository.upenn.edu/accounting_papers

Part of the Accounting Commons, and the International Business Commons

\section{Recommended Citation}

Christensen, H. B., Hail, L., \& Leuz, C. (2013). Mandatory IFRS Reporting and Changes in Enforcement. Journal of Accounting and Economics, 56 (2-3), 147-177. http://dx.doi.org/10.1016/ j.jacceco.2013.10.007

This paper is posted at ScholarlyCommons. https://repository.upenn.edu/accounting_papers/109

For more information, please contact repository@pobox.upenn.edu. 


\title{
Mandatory IFRS Reporting and Changes in Enforcement
}

\begin{abstract}
In recent years, reporting under International Financial Reporting Standards (IFRS) became mandatory in many countries. The capital-market effects around this change have been extensively studied, but their sources are not yet well understood. This study aims to distinguish between several potential explanations for the observed capital-market effects. We find that, across all countries, mandatory IFRS reporting had little impact on liquidity. The liquidity effects around IFRS introduction are concentrated in the European Union (EU) and limited to five EU countries that concurrently made substantive changes in reporting enforcement. There is little evidence of liquidity benefits in IFRS countries without substantive enforcement changes even when they have strong legal and regulatory systems. Moreover, we find similar liquidity effects for firms that experience enforcement changes but do not concurrently switch to IFRS. Thus, changes in reporting enforcement or (unobserved) factors associated with these changes play a critical role for the observed liquidity benefits after mandatory IFRS adoption. In contrast, the change in accounting standards seems to have had little effect on market liquidity.
\end{abstract}

\section{Keywords}

international accounting, IFRS implementation, regulation, enforcement, liquidity, European Union

Disciplines

Accounting | International Business 


\title{
Mandatory IFRS Reporting and Changes in Enforcement
}

\author{
Hans B. Christensen \\ Booth School of Business, University of Chicago \\ Luzi Hail \\ The Wharton School, University of Pennsylvania \\ Christian Leuz \\ Booth School of Business, University of Chicago \& NBER
}

November 2013

\begin{abstract}
In recent years, reporting under International Financial Reporting Standards (IFRS) became mandatory in many countries. The capital-market effects around this change have been extensively studied, but their sources are not yet well understood. This study aims to distinguish between several potential explanations for the observed capital-market effects. We find that, across all countries, mandatory IFRS reporting had little impact on liquidity. The liquidity effects around IFRS introduction are concentrated in the European Union (EU) and limited to five EU countries that concurrently made substantive changes in reporting enforcement. There is little evidence of liquidity benefits in IFRS countries without substantive enforcement changes even when they have strong legal and regulatory systems. Moreover, we find similar liquidity effects for firms that experience enforcement changes but do not concurrently switch to IFRS. Thus, changes in reporting enforcement or (unobserved) factors associated with these changes play a critical role for the observed liquidity benefits after mandatory IFRS adoption. In contrast, the change in accounting standards seems to have had little effect on market liquidity.
\end{abstract}

JEL classification: $\mathrm{G} 14, \mathrm{G} 15, \mathrm{G} 30, \mathrm{~K} 22, \mathrm{M} 41, \mathrm{M} 48$

Key Words: International accounting, IFRS implementation, Regulation, Enforcement, Liquidity, European Union

\footnotetext{
*We appreciate the helpful comments of an anonymous referee, Mary Barth (our discussant), Bob Holthausen, S.P. Kothari, Dave Larcker, Eddie Riedl, Jerry Zimmerman (the editor), and workshop participants at the 2012 IMO Conference at Harvard Business School, 2012 Journal of Accounting and Economics Conference, 2013 European Accounting Association meeting, Boston University, University of Bristol, Cass Business School, University of Chicago, Chinese University of Hong Kong, Dartmouth College, Erasmus University, University of Exeter, Humboldt University, Indiana University, London School of Economics, Norwegian School of Economics, Purdue University, Rice University, and Said Business School. We thank several technical partners at PwC's European offices as well as individuals at CESR/ESMA and various supervisory authorities for providing institutional details. We thank Laszlo Jakab, Maria Kamenetsky, Jeff Lam, Russell Ruch, and Michelle Waymire for their excellent research assistance. Christian Leuz gratefully acknowledges financial support by Chicago Booth's Initiative on Global Markets and Alexander von Humboldt Foundation's Humboldt Research Award.
} 


\section{Introduction}

In recent years, a large number of countries have made reporting under International Financial Reporting Standards (IFRS) mandatory. This switch is arguably the largest reporting standards change in accounting history and, not surprisingly, has been examined extensively (see, e.g., Barth, 2006; Hail et al., 2010; Soderstrom and Sun, 2007, for overviews). Much of the literature points towards positive and often substantial capital-market effects around IFRS introduction (e.g., Armstrong et al., 2010; Byard et al., 2011). However, following Daske et al. (2008), we note that the sources of these effects and, in particular, the extent to which they can be attributed to IFRS adoption remain unclear. Considering the continued trend towards worldwide IFRS reporting, a better understanding of the sources that led to the observed capitalmarket benefits is of fundamental importance to researchers, policy makers, and regulators.

Aside from conceptual reasons to be skeptical about the capital-market benefits from a switch to mandatory IFRS reporting (which we discuss in Section 2), there are several empirical concerns about the sources of the documented effects. First, many countries adopted IFRS reporting around the same time. This clustering in calendar time makes it difficult to empirically isolate the effects of IFRS reporting. Studies analyzing the capital-market outcomes of IFRS reporting could be confounded by unrelated institutional changes and/or economic shocks that happen to occur in the same time period. The adoption of IFRS in the European Union (EU) is a case in point. Starting with the Financial Services Action Plan (FSAP) in 1999, the EU passed a series of directives (e.g., on insider trading regulation) to improve financial market regulation, many of which were implemented around the time of IFRS adoption (e.g., Christensen et al., 2013a; CRA, 2009; FSAP, 1999). As Daske et al. (2008) discuss, these concurrent institutional changes could explain why they find capital-market effects around the introduction of mandatory 
IFRS reporting in the EU but not elsewhere. Consequently, they caution readers not to attribute the documented effects to IFRS adoption alone and highlight several alternative explanations.

Second, aside from unrelated shocks and changes that merely happen to be concurrent, it is also possible that institutional changes are explicitly tied to IFRS adoption. Again, the EU serves as an example. EC Regulation No. 1606/2002, which introduced IFRS reporting starting in 2005, requires member states to take appropriate measures to ensure compliance. As a result, many EU member states bundled IFRS adoption with changes in financial reporting enforcement. Such changes raise the possibility that the observed capital-market outcomes reflect at least in part enforcement changes with respect to financial reporting, rather than the switch in the accounting standards (see also Daske et al., 2008). Moreover, the switch in standards and the changes in enforcement could mutually reinforce each other. Understanding the relative roles of various institutional changes, and determining whether the observed capitalmarket effects around the time of mandatory IFRS adoption are indeed caused by the switch in accounting standards or something else is central to accounting research. The purpose of this paper is to further investigate the role of IFRS.

The above discussion highlights that IFRS studies face a potential correlated omitted variable and identification problem. Based on prior evidence, we can broadly distinguish between four explanations for the observed capital market benefits after IFRS adoption: (i) the switch from local GAAP to IFRS reporting played a primary role; (ii) IFRS adoption had capitalmarket benefits but only in countries with strong institutions and legal systems; (iii) countries make enforcement changes to support the introduction of IFRS, and it is this bundle that is responsible for the capital-market effects, and (iv) IFRS had little effect, but other institutional changes or economic shocks that are unrelated to financial reporting drive the observed capital- 
market benefits. ${ }^{1}$ We design a series of tests to distinguish between these explanations. We use panel-data techniques that estimate the liquidity effects within certain groups of countries and then compare these estimates across groups that differ with respect to IFRS adoption and enforcement changes to draw inferences about the potential role of IFRS reporting. To do so, we construct a novel dataset of whether and when substantive enforcement changes occurred in 56 IFRS and non-IFRS adoption countries from 2001 to 2009 by surveying national securities regulators, technical partners at PricewaterhouseCoopers, academics, and public sources.

Given the purpose of this study, the main analysis is centered on capital-market effects starting around the time of IFRS adoption. ${ }^{2}$ We examine market liquidity because it has a clear theoretical link to reporting quality, can be measured over short intervals, and is less anticipatory in nature than other economic constructs like cost of capital. The latter two features allow us to exploit (within-year) differences in the timing of IFRS adoption and (unrelated) institutional changes and hence to empirically separate them, which is difficult to achieve with capital-market outcomes that adjust slowly or are anticipatory in nature. Specifically, we use bid-ask spreads and a liquidity factor that combines four individual proxies of market liquidity, following Daske et al. (2008) and Lang et al. (2011). In the main analysis, we estimate quarterly panel regressions and include fixed effects for industry, country, and each quarter in EU, non-EU IFRS, and non-IFRS countries. Including separate quarter-year fixed effects for each of the three country groups implies that the coefficients of interest are estimated within group by comparing liquidity averages across realizations of the treatment variables in EU, non-EU IFRS, and non-

1 For (iii), the effects could be solely driven by enforcement changes, or alternatively, IFRS and enforcement changes could reinforce each other. To distinguish between these two possibilities in a two-by-two ANOVA, we would need all four cases plus independent assignment of IFRS and enforcement changes. Such data does not exist, which is why we only attempt to distinguish between explanations (i)-(iv). Furthermore, we note that for (iii) other factors that are correlated with the concurrent enforcement changes could play a role.

2 We estimate persistent level shifts in market liquidity (rather than short-term effects) in this study. We use the term 'around IFRS adoption' to indicate that the change in liquidity begins when IFRS becomes mandatory. 
IFRS countries, respectively. The time trends are fully flexible and should absorb unrelated shocks and liquidity trends within each group. The three specific country groups are motivated by prior evidence showing heterogeneity in the capital-market effects around IFRS adoption with effects concentrated in the EU (e.g., Daske et al., 2008). ${ }^{3}$ Our design also uses variation stemming from firms whose first-time IFRS reports fall in different quarters depending on their fiscal-year ends as well as firms that did not have to adopt IFRS at all or at a later point in time, for instance, because they released only legal entity financial statements or had only public debt securities outstanding. This variation enables us to also introduce separate quarter-year fixed effects per country and to provide within-country estimates as a sensitivity check.

We use binary indicator variables of whether and when countries made substantive changes to the enforcement of financial reporting over the sample period. Five EU countries (Finland, Germany, the Netherlands, Norway, and the U.K.) bundled IFRS introduction with a substantive change in enforcement, other countries (e.g., Sweden, Hong Kong, Turkey) made substantive enforcement changes after IFRS adoption, and one country (Japan) changed enforcement before having adopted IFRS. The changes include but are not limited to the creation of new supervisory agencies or the introduction of proactive reviews. While we deem these changes as substantive for the respective country, we note that the changes are not identical across countries (see Appendix for details).

The first set of tests using our panel-regression design confirms that the increase in market liquidity following IFRS adoption is concentrated in the EU. Next, we examine whether new EU directives (not directly tied to IFRS) are responsible for these liquidity improvements, rather than the IFRS mandate. We include indicator variables for five key EU directives that are part of the

3 We include Iceland and Norway in the EU sample as they belong to the European Economic Area (EEA) and agreed, inter alia, to adopt the EU capital market directives in exchange for access to the EU's single market. 
FSAP or, in our sensitivity analyses, use separate quarter-year fixed effects for each country, which control for arbitrary quarterly shocks to market liquidity in a country, including the effects of the FSAP directives. ${ }^{4}$ We still find significant market liquidity benefits around IFRS adoption in the EU. Thus, it is unlikely that concurrent EU directives or other unrelated economic shocks drive the liquidity changes, which largely rules out explanation (iv).

Next, extending Daske et al. (2008), ${ }^{5}$ we show that the liquidity benefits around IFRS adoption are not consistently present throughout the EU. They are limited to five EU countries that made substantive changes to their enforcement of financial reporting around the same time IFRS became mandatory. The enforcement changes are expected to become fully effective when firms start reporting under IFRS. While the results suggest that concurrent changes in reporting enforcement play a crucial role for the observed liquidity benefits around IFRS adoption, it is important to note that in these tests IFRS adoption and enforcement changes are bundled and hence cannot be separated. The magnitude of the coefficient estimates suggests an increase in liquidity between 18 and 23 percent relative to pre-IFRS liquidity levels, which we can translate into mean (median) trading cost savings between US\$ $0.35(0.11)$ and $1.5(0.29)$ million per year and sample firm, i.e., $0.09(0.06)$ to $0.22(0.16)$ percent of market value. This magnitude is clearly economically significant, when considering the recurring nature of the savings, but also not too large to be implausible.

$4 \quad$ Country-specific quarter-year fixed effects control for the effects of the FSAP directives because the directives apply to all firms trading on regulated markets from a certain (country-specific) quarter onwards. Firms from unregulated markets like the Alternative Investment Market in London (AIM) are excluded from our sample. See also Christensen et al. (2013a).

$5 \quad$ Even though there exist several research design differences between Daske et al. (2008) and our study (e.g. use of yearly versus quarterly observations, one versus five sample years post IFRS adoption, clustering of standard errors), the results are strikingly consistent. In fact, Daske et al. (2008) already caution "to attribute the capital-market effects for mandatory adopters solely or even primarily to the IFRS mandate" because "[m]any adopting countries make concurrent efforts to improve enforcement and governance regimes, which likely play into [the] findings" (p. 1086). Our study examines this conjecture. 
Our second set of tests establishes that the liquidity effects in the five EU countries do not simply reflect differences in the pre-existing level of enforcement or regulatory quality. As the countries with concurrent enforcement changes are all countries with relatively strong legal systems and a proven track record of implementing regulation, one could argue that our tests merely mirror prior work showing that capital-market effects around IFRS adoption are stronger or concentrated in such economies. To rule out explanation (ii) and disentangle enforcement changes from pre-existing regimes, we explicitly account for differences in regulatory quality when estimating the liquidity effects around IFRS introduction. ${ }^{6}$ We show that splitting our sample into countries with high and low regulatory quality does not lead to the same findings as splitting by concurrent enforcement changes. In particular, the liquidity effects in countries with high regulatory quality but without concurrent enforcement changes are statistically insignificant in most specifications and always significantly smaller than the effects in the five EU countries with bundled enforcement changes and IFRS adoption. Similarly, we find no liquidity effects outside the EU even in countries with high regulatory quality. The latter result is not a matter of power as the respective coefficients are generally close to zero and precisely estimated. Thus, our results are inconsistent with an interpretation that IFRS adoption yields liquidity benefits as long as the standards are properly enforced because it is difficult to argue that countries with strong institutions and legal enforcement as well as a strong past track record for implementing regulation well would not enforce IFRS.

The remaining tests examine settings for which IFRS adoption and changes in financial reporting enforcement occur at different times, allowing us to gauge the relative importance of

6 In the main analyses, we use the regulatory quality index from Kaufmann et al. (2009) as a proxy for a country's general ability to implement regulation and government policies. However, the results are robust to using other common measures for the quality of countries' legal and institutional systems, including the rule of law index (see Section 4.2). 
the two factors. Our third set of tests exploits the fact that some firms already report under IFRS on a voluntary basis and should experience only minor (or no) changes in the accounting standards when IFRS become mandatory. Yet, these firms are affected by enforcement changes that are introduced around the mandate. Thus, we analyze whether the liquidity effects around the IFRS mandate are different for voluntary adopters in countries with concurrent enforcement changes and voluntary adopters in countries without such changes. ${ }^{7}$ Market liquidity increases for voluntary IFRS adopters around the time IFRS reporting becomes mandatory but, consistent with our first test, only in EU countries with concurrent enforcement changes. The results suggest that changes in financial reporting enforcement play a crucial role for the liquidity benefits around IFRS adoption. They also cast doubt on the existence of widespread comparability (or network) effects from the IFRS mandate and are inconsistent with the explanation that IFRS adoption itself is the primary source of the capital-market benefits. However, these tests cannot rule out that IFRS (or, more generally, high-quality accounting standards) play some role for the liquidity effects, for instance, by being a precondition for enforcement changes to be effective.

In our fourth set of tests, we no longer center the analysis solely on IFRS adoption but also examine liquidity effects when countries change the enforcement of financial reporting at a different point in time. For instance, Sweden, Hong Kong and Turkey made substantive changes to the enforcement of financial reporting after they had moved to IFRS. For these countries, the effects of IFRS adoption and enforcement changes can be observed separately. However, they are still linked in the sense that IFRS adoption always precedes the enforcement changes. Thus, we do not observe enforcement changes independent of IFRS adoption. For this reason, we also

This test also controls for spillover or network effects from mandatory IFRS reporting on voluntary adopters (e.g., due to increased comparability) because such effects presumably occur in all IFRS countries. 
study liquidity effects in Japan, which made substantive enforcement changes in 2005, but has not yet moved to IFRS reporting. Although the enforcement changes are not necessarily comparable, these tests speak to the question of whether IFRS reporting is a necessary condition for enforcement changes to have liquidity effects. We find significant liquidity effects around substantive enforcement changes irrespective of whether countries already require IFRS reporting or have not yet adopted IFRS.

Our study contributes to the literature in several ways. First, it highlights that IFRS studies face major omitted variable problems by pointing to several potential explanations for the observed capital-market effects around IFRS adoption aside from the change in accounting standards itself. We propose an identification strategy that exploits novel data on institutional changes, the high frequency of liquidity data, corresponding fixed effects as well as differences in fiscal-year ends to distinguish between explanations. Second, we show liquidity effects after the IFRS mandate that are related to financial reporting. Thus, they are not spurious in the sense that they are driven by arbitrary shocks or changes in the institutional environment unrelated to financial reporting. As pointed out in Daske et al. (2008), spurious effects are a major concern, especially for the EU, and they are difficult to rule out in studies that rely on yearly observations and/or slow-moving capital-market proxies. That said, the finding that the observed liquidity effects are likely caused by improvements in financial reporting has to be interpreted carefully. It does not imply that IFRS adoption is responsible for the effects. Several of our results suggest otherwise. In particular, we show that IFRS adoption in countries with strong legal and regulatory systems does not necessarily yield liquidity benefits. In fact, there is no evidence of such benefits around IFRS adoption outside the EU regardless of the institutional environment. This evidence suggests that we should revisit prior findings demonstrating heterogeneous effects 
based on partitions of countries' pre-existing legal and institutional systems. Third, our results suggest that substantive enforcement changes play a critical role for the observed liquidity improvements around IFRS adoption. We show liquidity benefits for countries with enforcement changes, irrespective of whether they occur around the time of IFRS adoption, at a later point in time or, in the case of Japan, without having first moved to IFRS. While enforcement changes provide a plausible explanation, we emphasize that other concurrent (and therefore correlated) changes to the financial reporting system (e.g., audit regulation) could play into our findings as well. The purpose of this study is not to show the effect of enforcement but to study the role of IFRS. We conclude that the change to IFRS is unlikely to be the main or even an important driver of the observed capital-market effects.

In Section 2, we discuss related literature and develop alternative explanations for prior evidence. In Section 3, we outline the research design, describe the construction of a novel dataset with regulatory changes around the mandatory introduction of IFRS, and provide descriptive statistics on the sample. Section 4 contains the results of the four tests along with several robustness checks. Section 5 concludes.

\section{Prior evidence and alternative explanations for capital-market effects}

Considering the historical importance of global IFRS adoption as a regulatory event, it is not surprising that there are many empirical studies as well as an ongoing debate among academics, regulators, and practitioners about the effects of this change. To date, many studies document positive capital-market consequences after the mandatory switch to IFRS reporting (e.g., Brüggemann et al., 2013, for an overview). Among other things, studies show positive abnormal stock returns during important events leading up to IFRS adoption (Armstrong et al., 2010); an increase in market liquidity and decrease in cost of capital (Daske et al., 2008, 2013; Li, 2010; 
Florou and Kosi, 2013); more foreign investments in debt and equity instruments of firms domiciled in IFRS adopting countries (Beneish et al., 2010; DeFond et al., 2011; Brüggemann et al., 2012) together with a reduction in home bias among U.S. investors (Khurana and Michas, 2011; Shima and Gordon, 2011); higher information content of IFRS earnings (Landsman et al., 2012); an increase in stock price informativeness (Beuselinck et al., 2009); and improvements in financial analysts' information environment (Byard et al., 2011; Tan et al., 2011; Horton et al., 2013). ${ }^{8}$ Based on these findings, one could conclude that mandatory IFRS adoption has improved the transparency and comparability of financial statements as well as reduced information asymmetries.

However, this conclusion is premature for several reasons. First, it is conceptually not obvious why we would expect mandatory IFRS reporting to yield substantial capital-market effects. On one hand, adopting a single high-quality set of accounting standards could improve the transparency and comparability of financial statements. The idea is that better reporting and disclosure benefit capital markets, for instance, by reducing information asymmetries, increasing liquidity, and lowering the cost of capital (see, e.g., Hail et al., 2010, for details). But the counter argument is that financial reporting standards grant managers significant discretion in their application and, as a result, it is unclear whether forcing firms to use IFRS instead of local GAAP necessarily improves transparency and comparability. Adopting new standards is unlikely to alter managers' reporting incentives and the new standards might not fit a country's institutional environment (e.g., Ball et al., 2003; Burgstahler et al., 2006). Moreover, it is important to recognize that the IFRS mandate does not introduce accounting rules for the first

Evidence of changes in the properties of accounting earnings (rather than in capital market outcomes) around mandatory IFRS adoption is more mixed with several studies finding improvements in 'accounting quality' (e.g., Gordon et al., 2009; Gebhardt and Novotny-Farkas, 2011; Barth et al., 2012), while others find no or the opposite effects (e.g., Christensen et al., 2008; Atwood et al., 2011; Capkun et al., 2011; Ahmed et al., 2013). 
time. Countries had local accounting standards prior to IFRS, and these standards often were quite similar to IFRS, for instance, in the U.K., the Netherlands, or Norway (e.g., Bae et al., 2008). Thus, the counter argument does not imply that accounting standards do not matter at all. It simply contends that the change to IFRS may not have major effects, e.g., due to the discretion in the standards and the role of firms' reporting incentives (see also Daske et al., 2013).

Second, prior studies document substantial heterogeneity in the capital-market effects around IFRS adoption. Most of them find larger benefits for firms domiciled in countries with stronger legal and institutional systems. For instance, Daske et al. (2008) show that market liquidity increases after IFRS adoption, but only in the EU or in countries with strong rule of law. Similarly, Byard et al. (2011) find that analyst forecast errors and forecast dispersion decrease around mandatory IFRS adoption, but only in countries with strong legal regimes that also have large differences between local GAAP and IFRS. Landsman et al. (2012) show that the increase in information content of earnings announcements after IFRS adoption depends on the strength of countries' legal systems. One common interpretation of this evidence is that mandatory IFRS reporting yields significant capital-market benefits as long as countries have strong legal and institutional systems ensuring that the new standards are properly implemented and enforced. However, as discussed in the introduction, the clustered nature of IFRS adoption makes the analysis vulnerable to concurrent but unrelated economic shocks and institutional changes. If such confounding factors are correlated with the strength of countries' legal and institutional systems, they could explain the observed heterogeneity in the capital-market effects rather than differences in the implementation of the standards (e.g., Christensen et al., 2013a).

Third, countries could make other changes to the financial reporting system at the same time they introduce mandatory IFRS reporting. Moreover, these changes could be associated with the 
strength of countries' preexisting legal and institutional systems, explaining the aforementioned heterogeneity in the effects. For instance, countries could use the introduction of IFRS as an opportunity to improve enforcement of financial reporting. This bundling makes it even more difficult to attribute the observed capital-market effects. If the switch to IFRS and the change in enforcement are complements, for instance, because IFRS are easier to enforce, then the change in standards and enforcement have joint effects. It is also possible that the effects are additive in that each element contributes independently to the capital-market effects, or it could be that only one of the elements matters. Differentiating between these cases is difficult, especially considering that changes in the elements are unlikely to be independent or randomly assigned.

The introduction of IFRS in the EU provides an illustration of the empirical challenges. It is a particularly relevant case in light of prior evidence showing that the capital-market benefits around IFRS adoption are concentrated in the EU (e.g., Hail and Leuz, 2007; Daske et al., 2008; Li, 2010). Starting with the FSAP in 1999, the EU instituted a series of directives geared towards improving its financial market regulation (e.g., FSAP, 1999; CRA, 2009). One element of the FSAP is EC Regulation No. 1606/2002 (also called IAS Regulation), which requires the use of IFRS in the consolidated financial statements of most publicly traded firms domiciled in the EU as of the fiscal year beginning on or after January $1^{\text {st }}, 2005$. Compared to national GAAP requirements, the switch to IFRS often involves changes in the measurement rules as well as extensions in disclosure. ${ }^{9}$ Clearly, mandatory IFRS adoption marks an important regulatory event for the accounting systems of the EU member states. At the same time, the IAS Regulation also requires member states to take appropriate measures to ensure compliance with the new reporting standards (Berger, 2010). However, the IAS Regulation is not specific as to

For instance, using the Bae et al. (2008) metric of accounting differences between national GAAP and IFRS, the scores in the EU range from a low of one in the U.K. to a maximum of 18 (out of 21) in Luxembourg. 
what constitutes appropriate enforcement and how member states should achieve it. Hence, it affords member states significant latitude with respect to the enforcement of the IFRS mandate, which is what gives rise to concurrent changes in financial reporting enforcement in some but not all EU member states. Countries that choose to initiate enforcement changes concurrent to IFRS adoption are likely different from those that do not. In particular, it is possible that bundling countries make several changes to support the introduction of IFRS adoption, including but not necessarily limited to the concurrent enforcement changes. Such supporting changes imply that the observed effects cannot be attributed to IFRS adoption alone. ${ }^{10}$

Apart from the IAS Regulation and the ensuing changes in the enforcement of financial reporting, the FSAP brought numerous other legislative initiatives in the area of financial market regulation. Among the ones geared towards securities markets were the Market Abuse Directive on insider trading and market manipulation, the Transparency Directive (TPD) harmonizing reporting and disclosure requirements, ${ }^{11}$ the Prospectus Directive regulating disclosures during public security offerings, the Markets in Financial Instruments Directive on the provision of investment services across the EU, and the Takeover Directive, which provides a common framework for mergers and acquisitions, and takeover bids in the EU. All these directives were implemented over the 2004 to 2009 period, and because they potentially improve, or at least affect market liquidity, they could be confounding factors in an empirical analysis of IFRS adoption (see also Cumming et al., 2011; Christensen et al., 2013a).

10 Daske et al. (2013) make similar arguments for voluntary IFRS adoptions at the firm-level.

11 Among other things, the TPD requires EU countries to create or designate an enforcement agency that reviews the required information disclosures. Thus, this directive can be viewed as addressing the heterogeneous response among member states to the enforcement requirement of the IAS Regulation. As the TPD was implemented well after the IFRS mandate, it is unlikely to interfere with our analysis, which for the most part is centered on IFRS introduction. We confirm this claim in Table 3. The TPD however could play a role for our analyses in Table 6 , and hence we perform a sensitivity check to gauge its influence (see footnote 43 ). 
As the EU example and our discussion of the empirical challenges highlights, there are several potential explanations for the existence of significant capital-market effects around the introduction of mandatory IFRS reporting. We broadly distinguish between four explanations: (i) IFRS adoption played a primary role for the observed capital-market benefits; (ii) IFRS introduction had capital-market benefits, but only in countries with strong institutions and legal systems; (iii) a combination of IFRS adoption and concurrent enforcement (and possibly other) changes designed to support IFRS adoption is responsible for the capital-market effects; and (iv) IFRS had little effect, but other institutional changes or economic shocks that are unrelated to financial reporting drive the observed results.

\section{Research design and data}

\subsection{Identification strategy and empirical model}

We examine the sources of capital-market effects after the introduction of mandatory IFRS reporting using a large international panel dataset with quarterly firm-level observations. We focus on stock market liquidity as proxy of economic outcomes for three reasons. First, theory predicts that enhancing corporate transparency reduces information asymmetries in financial markets and hence increases market liquidity (e.g., Glosten and Milgrom, 1985; Diamond and Verrecchia, 1991; Verrecchia, 2001). Second, we can measure liquidity reliably over relatively short intervals. Third, liquidity is less anticipatory in nature than other economic constructs like cost of capital or firm value. ${ }^{12}$ These features are critical to our identification strategy as they allow us to measure liquidity changes around key events, i.e., when the first IFRS reports

12 While investors likely adjust market valuations or cost of capital estimates as soon as their expectations about future corporate transparency change, liquidity is less anticipatory because investors primarily worry about adverse selection and, hence, the level of transparency at the time they trade. It is of course possible that investors anticipate when buying shares that future improvements in transparency will reduce adverse selection at the time they sell. But this anticipatory effect is likely small. 
become available or when enforcement changes take effect, while controlling for general trends as well as other economic and regulatory shocks to liquidity over the sample period.

We illustrate our identification strategy and the coding of the main variables in Figure 1. Our empirical design has three key elements: variation in IFRS reporting, variation in enforcement changes, and the set of fixed effects. We describe each element in turn. First, we have variation in IFRS reporting across countries, firms, and over time. Our global sample comprises observations from countries that require IFRS reporting, mostly for fiscal years ending on or after December $31^{\text {st }}, 2005$ (firms \#1 and \#2 in Figure 1), and from countries without an IFRS mandate (firms \#5 and \#6). In addition, the sample includes firms that voluntarily switched to IFRS before it became mandatory (firm \#4). ${ }^{13}$ Including voluntary adopters in the analysis allows us to examine liquidity effects for a set of companies that does not have to change accounting standards when the IFRS mandate comes into effect. However, voluntary adopters are affected by other changes to the financial reporting system that apply to all firms and are meant to support IFRS adoption (e.g., stricter enforcement). As another source of variation, we include firms that do not have to report under IFRS (firm \#3). ${ }^{14}$ We identify firms that do not report under IFRS after the mandate based on the "accounting standards followed"

13 Voluntary adopters are drawn from Daske et al. (2013). While several countries permitted the use of IFRS in lieu of local GAAP even before the mandate (e.g., Germany, Russia), others did not (e.g., U.K., Canada). Not surprisingly, the proportions of voluntary adopters differ accordingly. To capture liquidity effects around the mandate, the IFRS variable does not switch to ' 1 ' until after IFRS become mandatory, even if the firm already voluntarily reported under IFRS before that date. Coding the voluntary switch (before the mandate) with a separate dummy does not affect our results. Similarly, dropping voluntary IFRS adopters from the sample (except for the analyses in Table 5) does not change the interpretation of the results.

14 In the EU, IFRS reporting is required for the consolidated financial statements of firms with equity securities traded on EU regulated markets. Firms that had only debt instruments or reported under U.S. GAAP could defer the application of IFRS for two more years after the initial start date of December $31^{\text {st }}, 2005$. Legal entity financial statements of traded firms, firms whose shares trade on non-regulated EU markets, as well as private firms are generally exempt from the IFRS requirement (ICAEW, 2007; Pownall and Wieczynska, 2012). 
field in Worldscope (field 07536). ${ }^{15}$ In most countries not all firms have the same fiscal-year end. As a result, firms released their first mandatory IFRS financial statements at different times (e.g., December $31^{\text {st }}, 2005$, vs. June $30^{\text {th }}, 2006$ ). We exploit the quarterly frequency of the liquidity data combined with the staggered release of the initial IFRS reports by coding the mandatory IFRS indicator so that it takes on the value of ' 1 ' beginning in the calendar quarter immediately following a firm's first fiscal-year end under the IFRS mandate (e.g., Q1/2006 for firm \#1 and Q3/2006 for firm \#2). Panel A of Figure 2 shows the resulting sample variation in the IFRS variable stemming from the initial rollout of mandatory IFRS reports. Not surprisingly, first-time IFRS reports are heavily concentrated in the four quarters of $2006 .{ }^{16}$ But there is also further variation in the years that followed. The staggered release of IFRS reports together with the inclusion of non-adopters help us control for unrelated liquidity trends and economic shocks.

The second key element of our empirical design is data on changes in reporting enforcement. We combine public sources (e.g., annual reports of national securities regulators) with a survey asking questions about changes in the enforcement of financial reporting over the sample period. We sent the survey to national securities regulators, the technical partners at PricewaterhouseCoopers and, in a few cases, academics. Based on this process, we identify five EU member states (Finland, Germany, the Netherlands, Norway, and the U.K.) with substantive

15 Voluntary adopters and non-adopters are clearly non-randomly selected firms. They are nevertheless useful benchmarks in our analysis. To mitigate concerns about these sample firms, we conduct sensitivity analyses that include separate fixed effects for the two types of firms and/or eliminate them from the sample. The results (not tabulated) are very similar to those reported and none of the inferences change.

16 Because of the large number of December fiscal-year end firms the initial rollout of IFRS reports is clustered in Q1/2006. However, our results also obtain if we drop these firms from the sample. This is possible because our identification does not exclusively rely on the staggered release of the IFRS reports, but also draws upon the existence of non-IFRS firms in quarters (and countries) when IFRS reporting firms are present. Thus, all observations for which there is variation in the IFRS indicator (i.e., IFRS $=0$ and IFRS $=1$ ) within a quarter and the group defined by the fixed-effects structure (i.e., EU or non-EU IFRS countries in the main analysis and individual country in the within-country analysis) contribute to the identification of the effects. 
changes in their enforcement of financial reporting around the time of the IFRS mandate. ${ }^{17}$

These countries created new enforcement agencies, moved to a proactive review process for financial statements to ensure compliance with IFRS, tightened penalties for violating accounting standards, increased resources available to supervisory authorities, or made other enforcement changes. The proactive review process is in some respects similar to the U.S. Securities and Exchange Commission's comment and review process. Given that none of the five countries had a risk-based, random sampling review process prior to IFRS adoption, we treat the introduction of proactive reviews as a key indication for a substantive shift in enforcement, but we recognize that it may be only one of several components. ${ }^{18}$ In addition to the five EU countries with bundled enforcement changes and mandatory IFRS adoption, we identify one country that changed enforcement before IFRS adoption (Estonia), and seven countries that did so after IFRS adoption but before the end of the sample period (Hungary, Ireland, Lithuania, Luxembourg, Sweden, Hong Kong, and Turkey). Finally, one country (Japan) made enforcement changes over the sample period but has not yet adopted IFRS (see Table 1). ${ }^{19}$ In the Appendix, we provide details on the survey and describe institutional changes in each country with a substantive shift in enforcement. Despite our best efforts, we acknowledge that the designation of a substantive shift in enforcement remains somewhat subjective.

17 Iceland also had a substantive enforcement change around IFRS adoption, but as we lack liquidity data prior to 2007, it does not contribute to the identification. Denmark tightened its reporting enforcement in 2005 when the Danish Securities Council was set-up. However, before that date, Denmark had already instituted a proactive review process and issued several enforcement actions under the old regime. Thus, the shift was perceived as more gradual and less substantive. As robustness check, we group Denmark with the five bundled countries and find that the results are very similar to those reported and none of the inferences change.

18 We are not interested in proactive reviews per se. We merely treat their introduction as a proxy for substantive enforcement changes. While in all five countries with bundled IFRS adoption, regulators switched to proactive reviews, we do not maintain that this is the only change or a necessary element. For example, in the U.K., the switch to proactive reviews already started in 2004, but our survey and various sources indicate that the substantive change did not take place until the second quarter of 2005 (see the Appendix for more details).

19 Chile is another country with substantive enforcement changes before IFRS adoption. However, the changes occurred during the second quarter of 2009 and were tied to the release of the initial mandatory IFRS statements in 2010. Thus, they occurred after our analysis. 
We define a binary $\triangle E N F$ indicator variable that takes on the value of ' 1 ' for each firm beginning in the calendar quarter immediately following the first fiscal-year end after the substantive enforcement change. The rationale for this coding is that the supervisory authorities review financial statements as they become available. Thus, the effects of tighter reporting enforcement likely occur when firms have prepared their financial statements and submit them to the regulator. To illustrate, firm \#1 in Figure 1 has a fiscal-year end of December $31^{\text {st }}$ and hence the $\triangle E N F$ variable is switched on beginning in Q1/2007. Note that in this example, IFRS is not bundled with enforcement, so IFRS and $\triangle E N F$ are independently coded. For the five bundled countries, IFRS and $\triangle E N F$ switch on at the same time and hence are identical because the enforcement changes were concurrent and generally tied to IFRS adoption. ${ }^{20}$ For firm $\# 2$ the initial annual reports under the stricter enforcement regime are not available until Q3/2007. This coding implies that enforcement changes have a staggered introduction as well. Figure 2, Panel B, shows the resulting sample variation from the initial rollout of substantive enforcement changes given the fiscal-year end distribution. It is apparent that the enforcement shifts are also fairly clustered in time, largely due to their bundling with IFRS adoption. However, we have some variation from Japanese firms that do not report under IFRS (contributing to the peak in mid-2006), as well as from firms in Sweden, Hong Kong, and Turkey (as visible in the 2008 and 2009 peaks). We use this variation to estimate liquidity effects around substantive changes in enforcement without simultaneous IFRS adoption.

20 Thus, to reflect bundling, the $\triangle E N F$ variable in Finland and the U.K. is not set to ' 1 ' until after 12/31/2005 (mirroring the IFRS variable), even though the substantive enforcement changes occurred earlier in 2005. See also footnote 47 . In our main analyses, we code $\triangle E N F$ in such a way that it applies only to IFRS adopting firms and not to firms reporting under local GAAP as there is anecdotal evidence that the newly created enforcement regimes did not target non-IFRS firms. When we relax this assumption (in Table 6) or re-run the main analyses with $\triangle E N F$ covering all local firms we find no liquidity improvements around enforcement changes for firms that do not adopt IFRS. This finding is consistent with the anecdotal evidence. Irrespective of this coding choice, our main inferences regarding the liquidity effects of IFRS adoption remain unchanged. 
Given the variation described for the first two elements above, we can introduce an extensive set of fixed effects to control for various sources of observed and unobserved heterogeneity in liquidity. This fixed-effects structure is the third element of our empirical design. It is intended to minimize correlated omitted variable (and related endogeneity) concerns. In our main specification, we include country, industry, and separate quarter-year fixed effects for three groups: the EU countries, non-EU but IFRS adoption countries, and nonIFRS countries. ${ }^{21}$ This fixed-effects structure implies that our main analysis provides withingroup estimates for the key variables of interest. That is, the quarter-year fixed effects eliminate all common shocks to liquidity within each of the three country groups in a given quarter, and the average liquidity effect is estimated using solely within-group variation in the variables of interest across firms (i.e., the IFRS and $\triangle E N F$ indicators). The choice of the three country groups is motivated by two reasons. First, prior research shows that the capital-market effects around IFRS adoption are concentrated in the EU (e.g., Daske et al., 2008). Second, non-IFRS countries could exhibit different liquidity trends than IFRS countries.

As explained above, our dataset exhibits within-country variation of when the IFRS mandate and the enforcement changes apply to a given firm. In addition, the dataset contains non-IFRS adopters. Thus, we can employ an even more extensive fixed-effects structure and introduce separate quarter-year fixed effects for each country. This specification amounts to withincountry estimation in that it only uses variation stemming from the staggered release of the first reports under the IFRS mandate (and/or the new enforcement regime) as well as the variation

21 An alternative specification would be to run separate regressions for each group. The main difference is that we do not impose the same coefficients on the firm-specific control variables in the liquidity model for each group. In our view, this is not a major restriction and, in fact, pooling all observations could help the estimation of the liquidity model. That said, we also provide results eliminating observations from non-IFRS benchmark countries (see Table 3). Furthermore, we obtain similar results and the same inferences when we estimate separate regressions for each of the three groups (not tabulated). 
due to non-IFRS adopters in a given country and quarter. The specification controls for arbitrary liquidity shocks to all firms in a given country and quarter, including liquidity effects due to regulatory changes that apply to all firms. Such changes could stem from the EU directives in the FSAP. These directives are introduced throughout the EU and apply to all firms traded on a country's regulated markets beginning on a specific date. Thus, their effects are absorbed by the country-specific quarter-year fixed effects. Alternatively, their effects can be controlled for with separate indicator variables marking the quarters when the directives enter into force (see also Kalemli-Ozcan et al., 2010, 2013; Christensen et al., 2013a).

For omitted factors to create spurious results in the within-country analysis, they would have to be correlated with the timing of IFRS introduction and/or enforcement changes across countries as well as the fiscal-year end distribution in these countries. Thus, the within-country analysis should be able to separate liquidity effects due to changes in financial reporting (e.g., IFRS, reporting enforcement or other changes to reporting system) from liquidity effects that are unrelated to financial reporting. At the same time, the within-country estimation is very demanding and eliminates a substantial amount of variation. ${ }^{22}$ We therefore use this specification as a sensitivity check only.

Combining the three elements of our empirical strategy, we obtain the following generic regression model (without firm and time subscripts):

$$
\text { Liq }=\beta_{0}+\beta_{1} \text { IFRS }+\sum \beta_{j} \text { Controls }_{j}+\sum \beta_{i} \text { Fixed Effects }_{i}+\varepsilon
$$

The dependent variable, Liq, stands for the liquidity proxies. IFRS is a binary variable marking firm-quarters with IFRS reporting after the mandate. Controls $s_{j}$ denotes a set of firm-

22 As one could argue that the within-country analysis risks "throwing out the baby with the bathwater," we explore several alternative fixed-effect structures in the sensitivity analyses (see Section 4.1). 
level control variables. Fixed Effects $s_{i}$ represents country, industry, and separate quarter-year fixed effects for the corresponding groups. As mandatory IFRS adoption and enforcement changes are regulatory initiatives that occur at the country level in specific time periods, we draw statistical inferences based on two-way clustered standard errors by country and calendar quarter. ${ }^{23}$ Eq. (1) does not include explanatory variables for concurrent changes in enforcement $(\triangle E N F)$ or for the level of regulatory quality. However, in subsequent tests, we sequentially expand Eq. (1) to allow the estimation of separate IFRS liquidity effects conditional on EU membership, the strength of the regulatory environment, and (bundled) changes in enforcement. Figure 3 illustrates our research strategy, which aims to distinguish between the four potential explanations for the observed liquidity effects after IFRS adoption. Panel B of Table 1 reports the binary indicators used in these tests to create non-overlapping subsets of sample countries. For instance, when we distinguish between EU countries that bundled the IFRS mandate with substantive enforcement changes, the remaining EU countries, and the IFRS adoption countries outside the EU, we estimate the following model (see also the second panel under the 'Test I' heading in Figure 3):

$$
\begin{aligned}
\text { Liq }= & \beta_{0}+\beta_{1} I_{F R S_{E U E N F}}+\beta_{2} I F R S_{E U \_n o n E N F}+\beta_{3} I F R S_{n o n-E U}+\sum \beta_{j} \text { Controls }_{j}+ \\
& \sum \beta_{i} \text { Fixed Effects } s_{i}+\varepsilon .
\end{aligned}
$$

In this model, we replace the single IFRS indicator from Eq. (1) with three separate (nonoverlapping) indicators for (i) the EU countries that switched to IFRS and, at the same time, implemented substantive enforcement changes $\left(I F R S_{E U_{-} E N F}\right)$, (ii) the remaining EU countries

23 As our panel data cover a relatively short period, clustering by calendar quarter can be problematic and lead to biased standard errors (Petersen, 2009, p. 460). We therefore check that one-way clustering at the country level produces similar results and inferences. Furthermore, clustering by 18 economic regions (e.g., Southern Europe, Central Europe, etc.) instead of by individual countries or clustering at the firm level does not change the interpretation of our tests (although it changes the significance levels of some coefficients of interest). 
without concurrent enforcement changes (IFRS $\left.S_{E U_{-} n o n E N F}\right)$, and (iii) the non-EU countries that also switched to IFRS reporting $\left(I F R S_{n o n-E U}\right)$. With this coding, we can directly compare the total liquidity effects of mandatory IFRS adoption across the three groups. The total group effects are easier to interpret than an interaction model that estimates the incremental effects of IFRS and enforcement changes using main effects and interaction terms. ${ }^{24}$ Apart from creating the false appearance of an ANOVA with two independently assigned treatments, this approach and, in particular, the use of a single label for the enforcement changes $(\triangle E N F)$ masks the fact that, unlike IFRS adoption, the enforcement changes across countries are not necessarily identical or even similar (see Appendix and Section 4.4).

\section{2. $\quad$ Sample and variable description}

Our sample period starts in the first quarter of 2001 and ends in the fourth quarter of 2009.

We include all firm-quarter observations for which we have the necessary liquidity and control variable data in Datastream and accounting standards information in Worldscope to estimate our basic regression model stated in Eq. (1). The sample comprises up to 35 IFRS treatment countries, of which 24 belong to the EU, and 21 benchmark countries. ${ }^{25}$ Table 1, Panel A, provides an overview of the sample composition by country, using the bid-ask spread sample as

24 As a technical matter, we can recast our model in Eq. (2) as an interaction model that is econometrically equivalent and yields exactly the same results and inferences. See Christensen et al. (2013b). To illustrate, a version of Eq. (2) without distinction between EU and non-EU countries using the interaction approach is: Liq $=\beta_{0}+\beta_{1}$ IFRS $+\beta_{2} \Delta E N F+\beta_{3}$ IFRS $^{*} \Delta E N F+\sum \beta_{j}$ Controls $_{j}+\sum \beta_{i}$ Fixed Effects $_{i}+\varepsilon$. Here, $\beta_{1}$ reflects the liquidity effects in IFRS countries without enforcement, $\beta_{2}$ the separate enforcement effects (without IFRS reporting), and $\beta_{3}$ the incremental liquidity effects in IFRS countries with (bundled or non-concurrent) enforcement changes (i.e., incremental to $\beta_{1}$ and $\beta_{2}$; thus the total effect relative to the benchmark sample is $\beta_{1}$ $+\beta_{2}+\beta_{3}$ ). Results from this simplified model are consistent with our findings. We find that the IFRS coefficient $\beta_{1}$ is insignificant, the enforcement coefficient $\beta_{2}$ is negative and highly significant, and the interaction term $\beta_{3}$ is negative but insignificant for the liquidity factor and significant for spreads. Christensen et al. (2013b) tabulates the results. This specification is less discriminating with respect to various treatments than 'Test IV' in Figure 3 and the corresponding analyses in Table 6.

25 We do not have the necessary data for several EU member states (Bulgaria, Cyprus, Latvia, Malta, and Romania). At the same time, we include Iceland and Norway in the EU sample because they belong to the European Economic Area (EEA) and adopt all EU capital market directives. The results are not sensitive to the inclusion of these countries. 
the basis. The sample comprises 613,752 firm-quarter observations. We exclude firms in IFRS countries that follow U.S. GAAP and firms with a U.S. cross-listing, which until 2007 meant reconciliation to U.S. GAAP. In addition, we eliminate firms trading on unregulated EU markets (e.g., the Alternative Investment Market AIM in London) as EU directives do not necessarily apply to them, drop very small firms with average market values below US\$ 5 million, and require benchmark countries to have at least 20 firms. $^{26}$

Panel A also lists the dates when IFRS reporting became mandatory, the calendar quarter during which the substantive change in enforcement took place (as detailed in the Appendix), and the Regulatory Quality index from Kaufmann et al. (2009). The latter index measures a government's ability to formulate and implement sound policies and regulations (as of 2003, i.e., before mandatory IFRS adoption). Higher values indicate better regulatory quality. In the last column, we report the number of firm-quarter observations from firms that voluntarily adopted IFRS before the mandate. Even though included throughout the analyses, we use these firms specifically to disentangle standards effects from enforcement effects in some of the tests that follow. Panel B of Table 1 lists the country-level coding of the binary indicator variables we use to build non-overlapping subsets of the sample that allow the estimation of total liquidity effects and comparisons across groups of countries and firms.

We present results for two liquidity measures. First, the Bid-Ask Spread is conceptually close to the desired construct and commonly used in empirical research to capture information asymmetry (e.g., Stoll, 1978; Venkatesh and Chiang, 1986; Glosten and Harris, 1988). We obtain the closing bid and ask prices for each day and compute the daily quoted percentage spread as the difference between the two prices divided by the mid-point. We then take the

26 Unregulated markets, such as the AIM, are the reason why the U.K., which typically ranks among the largest sample countries in international studies, has fewer observations than countries like Australia or Hong Kong. 
median daily spread over the quarter for a given firm. Second, to address measurement concerns about the spreads (e.g., because they are taken at the close of day when trading is low), we compute three more proxies for market liquidity and create an aggregate variable. Zero Returns is the proportion of trading days with zero daily stock returns out of all potential trading days per quarter. It is more widely available than spreads because it relies just on returns data. We compute Price Impact as the quarterly median of the Amihud (2002) illiquidity measure (i.e., daily absolute stock returns divided by US\$ trading volume). ${ }^{27}$ Total Trading Costs are an estimate of the total round trip transaction costs (including bid-ask spreads, commissions, and implicit costs from short-sale constraints or taxes) based on a quarterly time-series regression of daily stock returns on the aggregate market returns (Lesmond et al., 1999). ${ }^{28}$ For parsimony, we follow Daske et al. (2008) and Lang et al. (2012) and aggregate the four liquidity proxies into a single Liquidity Factor employing factor analysis, and use the factor scores from the first (and only) factor with an Eigenvalue greater than one as dependent variable. ${ }^{29}$

In terms of firm-level control variables, we follow prior literature and include firm size using the market value of equity, share turnover, and return variability (Chordia et al., 2000; Leuz and Verrecchia, 2000). We estimate the liquidity regressions in a log-linear form using the natural logarithm of the dependent variables and the control variables, and lag the control

27 To avoid the misclassification of days with no or low trading activity (i.e., days potentially yielding a price impact of zero), we omit zero-return days from the computation of the quarterly medians.

28 This measure is based on the logic that informed investors do not trade when the cost of trading exceeds the value of new information. Since private information is not observable, we use log-likelihood estimation to extract a proxy of total trading costs from a system of equations employing a panel of firms' daily stock returns and equal-weighted local market index returns. Following Lesmond (2005), we require at least 24 daily returns and 20 percent of the daily returns to be different from zero per firm-quarter. To reduce measurement error, we eliminate estimates below one basis point (see the appendix in Daske et al., 2008, for details on the estimation).

29 Using mean quarterly spreads and price impact instead of medians in the analyses or to form the liquidity factor does not affect the inferences from our tests. 
variables by four quarters. ${ }^{30}$ Price and volume data are from Datastream. ${ }^{31}$ We truncate all continuous variables at the first and $99^{\text {th }}$ percentile.

Table 2 reports descriptive statistics of the continuous variables used in the analyses, and in the table notes we provide further details on the variable measurement. The median firm is reasonably liquid with a bid-ask spread equal to one percent of share price. At the same time, there is substantial variation in liquidity across firms as indicated by the standard deviation. As the liquidity variables are negatively skewed, we use log-transformed measures in the regression analyses. All four individual liquidity measures are highly correlated with Pearson's correlation coefficients ranging from 0.47 to 0.80 . They are also well represented by the aggregate liquidity factor with correlations of 0.73 or better. For brevity, in the analyses that follow we tabulate and discuss only the results for Bid-Ask Spreads, which conceptually are the most appealing measure, and the Liquidity Factor, which aggregates the individual proxies. The table further shows that liquidity increases with firm size and share turnover, and decreases with more volatile returns.

\section{Liquidity effects of IFRS adoption and substantive changes in enforcement}

\subsection{Test I: IFRS adoption globally and in the EU bundled with enforcement changes}

In our first set of tests, we confirm that capital-market effects around IFRS adoption are concentrated in the EU. Next, we analyze whether unrelated economic shocks and other regulatory changes in the EU could explain the findings and whether liquidity effects differ across countries with and without concurrent enforcement changes. Table 3 presents the results of this analysis, and reports coefficient estimates and (in parentheses) $t$-statistics from estimating

30 In the Zero Return regressions we do not log transform the dependent variable. Because the Liquidity Factor can assume negative values we add one to the raw score before computing the natural logarithm.

31 Our primary source of bid-ask spread data is Datastream. To increase sample size in some of the smaller EU countries (i.e., Czech Republic, Luxembourg, Slovakia, and Slovenia) we complement this data with spreads from Bloomberg. For U.S. firms, we add spread data from CRSP because Datastream does not have this data in the early years of our sample period. Doing so does not materially affect the results. 
variations of Eq. (1) with bid-ask spreads (Panel A) and the liquidity factor (Panel B) as the dependent variable. As is common for liquidity models and given the extensive fixed-effects structure, the explanatory power of the regressions is high (between 65 and 80 percent). All firm-specific control variables are significant and have the expected signs.

In Model 1 of Table 3, we estimate Eq. (1) and include a separate set of quarter-year fixed effects for IFRS and non-IFRS countries. This structure allows for different trends in liquidity as well as arbitrary shocks to liquidity across IFRS and non-IFRS countries. The IFRS coefficient is insignificant in the bid-ask spread and liquidity factor regressions, suggesting that across all countries IFRS adoption has little systematic impact on market liquidity. ${ }^{32}$

In Model 2, we replace the single IFRS indicator variable with two non-overlapping binary indictors, one for all EU member states $\left(I F R S_{E U}\right)$ and one for the remaining IFRS adoption countries $\left(I F R S_{\text {non-EU }}\right)$. In addition, we introduce separate quarter-year fixed effects for EU member states, expanding the fixed effects structure to capture flexible time trends across the three groups (i.e., EU, other IFRS countries, and benchmark countries). In line with prior evidence, mandatory IFRS adoption is associated with a significant reduction in liquidity, but only in the EU and not in the remaining IFRS adoption countries. Finding heterogeneous results and, in particular, that the liquidity effects are limited to the EU already suggests that IFRS adoption alone is not the primary driver of the observed capital-market effects. But the finding does not discriminate between the other three explanations. The liquidity effects in the EU could be explained by stronger legal and regulatory quality in the EU compared to the rest of the IFRS

32 If we cluster the standard errors by firm, the IFRS coefficient becomes significant in the liquidity factor regression. Yet, this (average) finding is misleading and masks that the effect is driven by EU observations and, more specifically, by countries with concurrent enforcement changes. See also Christensen et al. (2013b). 
countries, by other regulatory changes such as those following the FSAP, or by bundling IFRS adoption with substantive enforcement changes in some EU countries, but not outside the EU.

To rule out explanation (iv), other regulatory changes and arbitrary shocks to liquidity, we include explicit control variables for the introduction of several key directives in the FSAP, namely the Market Abuse Directive (MAD), the Transparency Directive (TPD), the Takeover Directive (Takeover), the Market in Financial Instruments Directive (MiFID), and the Prospectus Directive (Prospectus). Alternatively, we re-estimate the model with separate quarter-year fixed effects for every country. This design controls for arbitrary liquidity shocks common to all firms in a given country and quarter and uses only within-country variation in IFRS adoption across firms as well as in firms' fiscal-year ends to identify the IFRS variables (see also Figure 1). ${ }^{33}$ Consistent with Christensen et al. (2013a), the coefficients on MAD and TPD are significantly negative, while the other EU directives are insignificant (see Table 3). However, the IFRS $E U$ coefficient is not affected by the additional controls in Model 3 and only slightly smaller in magnitude for the bid-ask spreads in Model 4. Thus, it is unlikely that the five directives or other economic shocks unrelated to financial reporting are responsible for the observed liquidity effects around the IFRS mandate, despite the fact that some of these directives came into force at around the same time as the switch to mandatory IFRS reporting.

To gauge the extent to which our findings are sensitive to the inclusion of observations from benchmark countries, we next eliminate firms from non-IFRS countries. The results remain largely unchanged, regardless of whether we use two separate quarter-year fixed effects (Model 5) or within-country estimation (not tabulated). We obtain similar results when we limit the

33 Because EU directives enter into force as of a given date and affect all sample firms in a country at the same time, we cannot separately introduce indicators for the directives once we apply within-country estimation. 
sample to EU firms only or when we drop (one-by-one) the three largest treatment countries in the EU from the sample (i.e., the U.K., Germany, and France).

In the last two columns of the table we explore explanation (iii) and compare the liquidity effects in countries in which IFRS and the enforcement changes are bundled to the effects in countries without such bundling. Specifically, in Models 6 and 7, we estimate Eq. (2), which distinguishes between EU countries that bundled the IFRS mandate with enforcement changes $\left(I F R S_{E U_{-} E N F}\right)$, the remaining EU countries $\left(I F R S_{E U_{-} n o n E N F}\right)$, and IFRS adoption countries outside the EU $\left(I F R S_{n o n-E U}\right)$. Liquidity increases significantly only in those EU countries that bundle IFRS adoption with enforcement changes. No such increase is present in the other EU countries without concurrent enforcement changes, or outside the EU. The IFRS $S_{E U \_n o n E N F}$ coefficient is insignificant in all specifications and much smaller than the IFRS $S_{E U_{-} E N F}$ coefficient. $^{34}$ Thus, consistent with explanation (iii), the results suggest that concurrent changes in reporting enforcement (or other factors associated with these enforcement changes) play a crucial role for the liquidity benefits around IFRS introduction.

Based on the coefficient estimates for the liquidity factor, liquidity improves in the five countries with bundled enforcement between 18 and 23 percent relative to pre-IFRS liquidity levels. $^{35}$ To further gauge the economic magnitude, we translate these percentages into annual trading cost savings for the mean and median sample firm. We multiply the estimated trading cost reductions with the yearly dollar trading volume per firm and then aggregate over firms. For bid-ask spreads, the mean (median) cost savings are on the order of US\$ $0.35(0.11)$ to 0.45

34 The IFRS $S_{E U E N F}$ coefficient is different from the other two IFRS coefficients at a 5\% level or better, except for spreads using within-country estimation when the difference is close to being significant (11\%; two-sided).

35 We compute the percentage effects for the liquidity factor as $\left(e^{-0.259}-1\right)=-0.23$ and $\left(e^{-0.195}-1\right)=-0.18$. The individual liquidity proxies are slightly more dispersed and produce percentage effects of -0.35 to -0.17 (bidask spreads), -0.25 to -0.22 (total trading costs), and -0.13 to -0.14 (zero returns). The coefficients in the price impact regressions are insignificant. 
(0.15) million, or $0.09(0.06)$ to $0.11(0.07)$ percent of market value per firm and year. For total round-trip trading costs, the mean (median) savings lie in the range of US\$ $1.2(0.23)$ to 1.5 (0.29) million, or $0.17(0.13)$ to $0.22(0.16)$ percent of market value. These numbers are clearly economically significant, in particular when considering the recurring nature of the savings, but at the same time not too large to be implausible. At the same time, these savings need to be interpreted cautiously as the analysis is limited to liquidity and does not consider any costs from IFRS adoption or substantive enforcement changes. Thus, the analysis is silent on the net effects of the regulatory changes but shows that the switch to IFRS alone is unlikely to explain the observed liquidity changes around IFRS adoption.

In additional tests (not tabulated), we find further support for the importance of enforcement changes by examining cross-sectional differences among the five IFRS $S_{E U_{-} E N F}$ countries. Presumably, if IFRS reporting played a primary role, we should find bigger effects in countries for which the switch to IFRS resulted in bigger changes in the accounting standards. Using the Bae et al. (2008) measure for accounting differences between IFRS and pre-existing GAAP, we find the opposite result. That is, the liquidity effects are generally larger in countries with smaller GAAP differences, which is inconsistent with explanation (i). But as the cross-sectional variation is limited to five countries, this result should be interpreted cautiously.

We also assess the sensitivity of the results to the fixed-effects structure of our empirical models. In particular, the within-country specification severely restricts the variation that is used to estimate the effects of IFRS adoption and enforcement changes, and risks "throwing out the baby with the bathwater." We therefore explore several alternative fixed-effect structures that replace the (demanding) country-quarter fixed effects, but still tighten the specification relative to the three-trend base model: first, to control for firm-specific time-invariant variables, we 
replace country- and industry-fixed effects with firm-fixed effects. ${ }^{36}$ Second, since the liquidity models might vary across countries (and over time), we interact the firm-level control variables with country fixed effects (e.g., country*size). Third, we add separate quarter-year fixed effects for developed markets to allow for the possibility that emerging and developed economies exhibit different liquidity trends. Fourth, we include separate size coefficients in each quarter (size*year-quarter) to accommodate liquidity shocks that affect large firms differently than small firms. Finally, we address the concern about overstated $t$-statistics that can arise in difference-indifferences regressions with a large number of observations from the same firm (Bertrand et al., 2004). For each firm, we collapse the time-series into a single observation pre- and post-IFRS by computing means. None of these variations (not tabulated) materially alter the results, and the inferences remain unchanged.

Finally, to assess the influence of differences in sample size across countries, we re-run the analyses after dropping sample countries with fewer than 500 firm-quarter observations or estimating weighted least squares regressions with the inverse of the number of firm-quarters per country as weights (i.e., giving less weight to countries with many observations). In both cases the inferences from our tests are not affected.

\subsection{Test II: Effect of regulatory quality on IFRS adoption and enforcement changes}

Our second set of tests examines whether the liquidity effects in the five EU countries stem from explanation (ii) and simply reflect pre-existing differences in the level of enforcement or in regulatory quality. The five countries with concurrent enforcement changes are all countries with relatively strong legal systems and a proven track record of implementing regulation (see Table 1). Thus, one could argue that our results merely mirror prior work showing that capital-

36 Introducing firm-fixed effects is equivalent to estimating a specification in changes. The identification comes solely from within-firm variation in the variables of interest, i.e., changes over time. 
market effects around IFRS adoption are concentrated in such economies and that the lack of effects in countries without bundled enforcement changes could be due to the fact that this latter group also includes countries of low regulatory quality. To disentangle enforcement changes and pre-existing differences in legal and regulatory systems, we expand our regression model to account for the role that regulatory quality (and other institutional proxies) plays for the liquidity effects around IFRS adoption, and report results in Table 4.

First, in Model 1, we split all treatment sample countries (EU and non-EU) into two groups based on the sample median of the regulatory quality index from Kaufmann et al. (2009). We then estimate the liquidity effects of IFRS adoption in high $\left(I F R S_{\text {High }}\right)$ and low $\left(I F R S_{\text {Low }}\right)$ regulatory quality countries using two non-overlapping indicator variables (see Table 1, Panel B). We find a negative but insignificant association between IFRS adoption and both liquidity variables in countries with high regulatory quality. The coefficient on IFRS adoption in low regulatory quality countries is insignificant. Thus, a simple sample split into countries with high and low regulatory quality does not generate findings similar to those in Table 3.

Next, we exploit the variation in regulatory quality among the EU countries that do not bundle IFRS adoption with substantive changes in reporting enforcement, and condition the analysis on both regulatory quality and EU membership. That is, aside from the five countries with bundled enforcement changes $\left(I F R S_{E U_{-} E N F}\right)$ we form the following subgroups: EU countries with high regulatory quality but without change in reporting enforcement at the time of IFRS adoption $\left(I F R S_{E U_{-} n o n E N F_{-} H i g h}\right)$, EU countries with low regulatory quality $\left(I F R S_{E U_{-} n o n E N F_{-} L o w}\right)$, and the same two groups for non-EU countries $\left(I F R S_{n o n-E U_{-} H i g h}\right.$ and $\left.I F R S_{\text {non-EU_Low }}\right)$. The coefficient on $I F R S_{E U_{-} n o n E N F_{-} H i g h}$ is of particular interest, because it lets us separate the levels effect of regulatory quality, which should affect all countries with high regulatory quality (i.e., both 
$I F R S_{E U_{-} E N F}$ and $I F R S_{E U_{-} n o n E N F_{-} H i g h}$, from the changes effect, which should only be present in the countries with concurrent enforcement changes $\left(I F R S_{E U_{-} E N F}\right)$.

In Models 2 and 3 of Table 4, we present the main variables of interest using the three-trend fixed effects structure and, alternatively, within-country estimation. Throughout, the $I F R S_{E U_{-} E N F}$ coefficient is significantly negative. Moreover, it is significantly smaller in magnitude (i.e., more negative) than the coefficients for any other subgroup, except in one case (comparing $I F R S_{\mathrm{EU} U_{-} \mathrm{ENF}}$ and $I F R S_{\mathrm{EU} U_{-} \text {nonENF_Low }}$, which is likely lack of power considering that $I F R S_{E U_{-} E N F}$ is significantly larger than $I F R S_{E U_{-} n o n E N F_{-} H_{i g h}}$ in all instances. For the bid-ask spreads, all the other IFRS coefficients are small in magnitude and never significantly negative. We find the same results for the liquidity factor, except for the last model, in which the IFRS $S_{E U_{-} n o n E N F_{-} \text {High }}$ coefficient is significantly negative.

With respect to the role of IFRS adoption, it is particularly noteworthy that the liquidity effects in EU countries with high regulatory quality but without concurrent enforcement changes are generally indistinguishable from zero. But even if they were significantly negative (as in Model 3 for the liquidity factor), this result does not imply an IFRS effect. It could also reflect smaller or more gradual changes in enforcement that were not viewed and coded as substantive (i.e., $\triangle E N F=0$ ). Denmark is such a case (see footnote 17). Consistent with this explanation, $I F R S_{E U_{-} n o n E N F_{-} H i g h}$ is smaller if we drop Denmark from the sample or reclassify it as having a substantive change. Moreover, there are no liquidity benefits outside the EU, even in countries with strong legal institutions and high regulatory quality. ${ }^{37}$ The $I F R S_{\text {non-EU_High }}$ coefficient is close to zero and economically insignificant, especially for the liquidity factor, and hence it is not a matter of power. Thus, the findings in Table 4 are inconsistent with the interpretation that

37 We do not have an explanation for why the IFRS $S_{\text {non-EU_Low }}$ coefficient is significantly positive in the withincountry estimation. 
IFRS adoption yields positive liquidity effects as long as the standards are enforced (properly). Countries with strong legal systems and high regulatory quality are expected to enforce IFRS properly. But that being the case, it is difficult to explain why we do not see significant liquidity effects around IFRS adoption in these countries. For instance, in a country like Australia, which historically has an enforcement regime similar to the U.K. and therefore, one would think, reasonable enforcement mechanisms for IFRS (but no concurrent enforcement change), we do not observe significant liquidity effects around IFRS adoption.

In additional tests (not tabulated), we confirm that the findings in Table 4 do not depend on the specific partitioning variable. We repeat the analyses with various alternative proxies for a country's institutional strength: the code law versus common law distinction, the differences between national GAAP and IFRS (Bae et al., 2008), the Kaufmann et al. (2009) rule of law index, an aggregate measure of reporting incentives, ${ }^{38}$ a country-level measure of earnings management (Leuz et al., 2003), and the anti-self dealing index from Djankov et al. (2006). For each of these variables, the results are similar to those reported in Table 4.

Moreover, when we compare the means (medians) of these institutional variables in the EU countries with bundled enforcement changes to the means (medians) in the remaining high regulatory quality countries in the EU (without such enforcement changes), none of the differences are statistically significant. The two groups of countries do not differ materially in terms of the level of institutional strength or regulatory quality. Thus, it is difficult to argue that countries in the IFRS $E_{E U E N F}$ group implement and enforce IFRS more rigorously than countries in the $I F R S_{E U_{-} \text {nonENF_High }}$ group.

38 We follow Daske et al. (2013) and first estimate individual firms' reporting incentives using factor analysis to extract a single factor based on several firm characteristics (size, leverage, return on assets, book-to-market, closely held shares, and foreign sales). We then compute the country-level mean incentives score, which we use to partition the treatment sample into above and below median reporting incentives countries. 
In sum, the results so far largely rule out explanations (i), (ii), and (iv). The results are generally supportive of explanation (iii) and suggest changes in enforcement as a possible confounding factor for the liquidity effects around IFRS adoption. However, the findings do not imply that IFRS adoption plays no role. The switch to IFRS and the change in enforcement could be complements and jointly contribute to the liquidity effects.

\subsection{Test III: Enforcement changes and voluntary IFRS adopters}

Our third set of tests attempts to shed further light on the roles of IFRS adoption and concurrent enforcement changes using variation within the five EU countries for which the two events are bundled. We exploit the fact that some firms already reported under IFRS on a voluntary basis when IFRS became mandatory (i.e., EU firms that switched to IFRS before 2005 like firm \#4 in Figure 1). For these firms, mandatory IFRS reporting does not imply a substantial change in the accounting standards. Yet, voluntary IFRS adopters are affected by concurrent enforcement changes. Thus, we analyze whether the liquidity effects around the IFRS mandate are different for voluntary adopters in countries with concurrent enforcement changes versus voluntary adopters in countries without such changes.

Towards this end, we split the IFRS $S_{E U_{-} E N F}$ and IFRS $S_{E U_{-} n o n E N F}$ coefficients from Eq. (2) into non-overlapping binary indicators for voluntary (vol_IFRS $S_{E U \_N F}$ and vol_IFRS $\left.S_{E U \_n o n E N F}\right)$ and first-time mandatory adopters (man_IFRS $S_{E U_{-} E N F}$ and man_IFRS $\left.S_{E U_{-} n o n E N F}\right)$. The regression models are very similar to those in our main specification in Table 3, except that we add a fixed effect for voluntary IFRS firms (i.e., an indicator variable set to ' 1 ' if an EU firm voluntarily adopts IFRS at any point before the mandate). This variable controls for all (time-invariant) 
differences in liquidity between voluntary adopters and the other firms in the sample, which is important considering that the former group is a self-selected subset. ${ }^{39}$

Table 5 reports results using the three-trend fixed effects structure (Model 1) and withincountry estimation (Model 2). Consistent with Table 3, we find that liquidity increases around the time of the IFRS mandate for voluntary IFRS adopters, but only in the five EU countries with concurrent enforcement changes. That is, for both liquidity variables the vol_IFRS $S_{E U_{-} E N F}$ coefficient is significantly negative and different from the (insignificant) vol_IFRS $S_{E U \_n o n E N F}$ coefficient. We also note that the magnitude of the liquidity effects for voluntary and mandatory adopters in countries with concurrent enforcement changes are similar in most cases and statistically not different from each other (i.e., we cannot reject the null that vol_IFRS $S_{E U_{-} E N F}=$ man_IFRS $\left.S_{E U_{-} E N F}\right)$. However, if there were a joint effect from IFRS adoption and enforcement changes, we would predict that, ceteris paribus, mandatory adopters exhibit larger effects than voluntary adopters. The results do not support this prediction. Instead, they suggest that the liquidity effects primarily reflect concurrent changes in enforcement (and possibly other related factors in these five countries). Even then, concurrent or prior IFRS adoption could still be a pre-condition for liquidity effects to occur, in which case voluntary adopters might not have seen liquidity increases had they not adopted IFRS in the first place. However, we question how plausible this explanation is considering that the five countries had local standards, which had developed over a long time and, in several cases, were fairly close to IFRS (Bae et al., 2008).

39 In additional tests (not tabulated) we perform the analyses in Table 5 controlling for several firm attributes that might explain voluntary IFRS adoption (i.e., financial leverage, return on assets, book-to-market, percentage of closely held shares, and percentage of foreign sales); after eliminating sample countries without voluntary IFRS adopters (see Table 1, Panel A); dropping firms that might have adopted IFRS in anticipation of the mandate (i.e., in or after 2002, the year the EU Commission passed the IAS Regulation); and adding an indicator variable that switches on after the first voluntary IFRS report. For all these analyses, the results are very similar, and none of our inferences change. 
The results in Table 5 also speak to the question of how likely it is that there are spillover or network effects from mandatory IFRS adoption (e.g., due to better comparability). Daske et al. (2008) discuss as possible explanation that liquidity improvements for voluntary adopters in the year of the introduction of mandatory IFRS could stem (among other things) from network or comparability effects that occur when mandatory adopters shift to the same accounting standards. But the evidence that the liquidity effects are present only in the countries with bundled enforcement changes casts doubt on the existence of widespread comparability (or network) effects from the IFRS mandate, at least as far as market liquidity is concerned. ${ }^{40}$

\subsection{Test IV: Separating the effects of IFRS adoption and enforcement changes}

So far, our evidence supports explanation (iii) and suggests that changes in financial reporting enforcement are crucial for the observed liquidity benefits. But we cannot rule out that IFRS reporting (or, more generally, high-quality accounting standards) are a pre-condition to obtain liquidity improvements around enforcement changes. We therefore exploit that some countries made changes to the enforcement of financial reporting that do not coincide with IFRS adoption. For instance, Sweden and Hong Kong made substantive changes to the enforcement of financial reporting in 2007 and 2008, respectively, but moved to IFRS reporting in 2005. Similarly, Turkey made enforcement changes in 2008, but moved to IFRS in 2006. For these countries, we can estimate liquidity effects around the IFRS mandate and, separately, around the change in enforcement (see also firms \#1 to \#4 in Figure 1). Admittedly, in all those cases, IFRS still precedes the enforcement changes. To speak to the question of whether enforcement changes result in liquidity improvements without prior IFRS adoption, we study liquidity effects

40 Following Daske et al. (2008), Table 7, we split the IFRS observations in the EU into observations from industries with a high or low proportion of voluntary IFRS adopters prior to the mandate. If positive externalities are present, we expect the liquidity effects for the voluntary adopters to be greater in industries with low prior adoption rates. We do not find evidence of such a differential reaction (results not tabulated). 
in Japan, as it made substantive enforcement changes in 2005 but has not yet moved to IFRS reporting (firm \#5 in Figure 1). Japan is relevant for our analysis because it gives us a change in reporting enforcement for an accounting regime of arguably lower quality than IFRS. ${ }^{41}$

We first estimate the liquidity effects around enforcement changes in EU countries that did not bundle them with the IFRS mandate. There are five countries that fall in this category (Estonia, Hungary, Ireland, Lithuania, and Sweden). We define a separate binary indicator variable that captures the initiation of the enforcement changes $\left(\Delta E N F_{E U}\right)$. We include this new variable in a regression together with $I F R S_{E U_{-} E N F}$, capturing liquidity effects in the EU countries with bundled IFRS adoption, and $I F R S_{n o n-E U}$ for the remaining IFRS countries.

Model 1 in Table 6 shows the results of this analysis. We report results from the threetrends fixed effects specification only because we have even less variation from fiscal-year ends around substantive enforcement changes than around IFRS adoption (see the time-series patterns in Figure 2) ${ }^{42}$ We find negative coefficients for $\triangle E N F_{E U}$, but the effect is statistically significant for the liquidity factor only. For spreads, the effect is close to conventional significance levels even though the estimated magnitude of the liquidity effect is larger (around 16 percent versus 5 percent for the liquidity factor). ${ }^{43}$ The IFRS $S_{E U}$ nonENF coefficient is not significant and indicates no discernible liquidity effect around IFRS introduction. However, because there are relatively

41 Unlike many developed countries, Japan did not initiate a project of achieving convergence between local GAAP and IFRS until 2005. Hence, Japanese GAAP is arguably (more) distinct from IFRS. Consistent with this conjecture, Bae et al. (2008) indicate nine major areas of accounting differences. Moreover, Japanese financial reporting has traditionally been viewed as being of relatively low quality from an information or capital-markets perspective (e.g., Ball et al., 2000; Leuz et al., 2003).

42 Nevertheless, the results for Table 6 are very similar using within-country estimation, and if anything, slightly stronger than those tabulated (in particular using spreads as the dependent variable). The same holds when we include separate fixed effects for voluntary adopters and non-adopting firms in the analysis.

43 In EU countries, enforcement changes after IFRS adoption could be related to the TPD (see also footnote 11). The TPD stipulates, among other things, that each EU country must have a supervisory authority that examines firms' regulated disclosures (which includes IFRS financial statements). Thus, as a sensitivity check, we code $\triangle E N F_{E U}$ as the earlier of either the substantive enforcement change in Table 1 or the entry-into-force of the TPD (not tabulated). With this coding, $\triangle E N F_{E U}$ is negative and becomes strongly significant, but consistent with Christensen et al. (2013a) only in countries with high prior regulatory quality. 
few observations from EU countries with asynchronous enforcement changes, except for Sweden, the power of this test is likely small.

We therefore expand the analysis to substantive enforcement changes globally. That is, aside from countries with bundled IFRS adoption (which all happen to be in the EU, i.e., $\left.I F R S_{E U_{-} E N F}\right)$, we separately estimate the liquidity effects around enforcement changes in all IFRS countries $\left(\triangle E N F_{\text {IFRS }}\right)$ as well as in Japan $\left(\Delta E N F_{\text {Japan }}\right)$. In addition, we estimate a single coefficient for the IFRS effects in all countries without bundled enforcement changes $\left(\right.$ IFRS $\left._{\text {nonENF }}\right)$ in Model 2. In Model 3, we distinguish between IFRS countries with and without substantive enforcement changes over the sample period (IFRS $S_{n o n E N F 1}$ and $\left.I F R S_{\text {nonENF2 }}\right)$. The latter specification allows us to assess whether the liquidity effects around IFRS adoption differ in countries with subsequent enforcement changes, perhaps because firms anticipate when they adopt IFRS that enforcement of financial reporting is going to be tighter in the future.

As Table 6 shows, enforcement changes that occur at different times than the IFRS mandate are associated with a significant increase in liquidity. The $\triangle E N F_{I F R S}$ coefficient is significantly negative and reasonably close in magnitude to the $I F R S_{E U_{-} E N F}$ coefficient. For instance, using the liquidity factor, the results indicate a 16-percent increase in liquidity following the enforcement change, which is statistically indistinguishable from the 24 percent increase around the bundled effects of IFRS and enforcement changes. The enforcement effect in Japan is also significantly negative. For the liquidity factor, the effects in Japan amount to a 15 percent increase in liquidity and are very similar to those in IFRS countries with enforcement changes. However, we caution to read too much into a comparison of coefficient magnitudes, as the regulatory changes themselves differ across countries and are probably less comparable for enforcement than for IFRS adoption. At a minimum, the results show that (prior) IFRS adoption 
is not necessary to obtain liquidity benefits around enforcement changes. Moreover, none of the IFRS coefficients in Table 6 are significant.

Overall, we find significant liquidity effects around substantive enforcement changes when they are not concurrent with IFRS adoption as well as in Japan where they occur without IFRS reporting. At the same time, we find no evidence of liquidity benefits around IFRS adoption when we estimate the effects for countries that solely adopt IFRS reporting.

\section{Conclusion}

Prior studies have documented significant capital market benefits following the introduction of mandatory IFRS reporting. This paper examines the sources of those benefits. Prior work shows that the effects around IFRS adoption are significantly stronger in countries with stricter and better functioning legal systems, and that they are stronger in the EU than in other regions of the world. We argue that this evidence is consistent with several interpretations and that it is still an open question to what extent positive capital-market effects around mandatory IFRS adoption are indeed attributable to arguably improved and globally harmonized accounting standards.

We use panel-data techniques to analyze quarterly market-liquidity data, and rely on withinand across-country variation in the timing of IFRS adoption and of other institutional changes to distinguish between several possible explanations. Specifically, we explore whether (i) the switch from local GAAP to IFRS reporting played a primary role for the observed capital-market benefits; (ii) the IFRS mandate had capital-market benefits, but only in countries with strong institutions and legal enforcement; (iii) countries made enforcement (and possibly other) changes to support the introduction of IFRS and it is this bundle that drove the capital-market effects; or

(iv) the effects around IFRS are spurious because other institutional changes and/or economic shocks unrelated to financial reporting are responsible for the observed capital-market benefits. 
We show that, across all countries, mandatory IFRS reporting had little impact on liquidity. Consistent with prior work, the liquidity effects around IFRS adoption are concentrated in the countries of the EU. However, we show that the observed liquidity effects are not driven by other EU Directives and/or unrelated economic shocks. Thus, the effects appear to be (causally) driven by changes in the financial reporting environment, ruling out explanation (iv). However, they could reflect IFRS adoption, concurrent changes in reporting enforcement, or other related improvements to the reporting system. Next, we show that the liquidity effects are confined to those EU countries that made substantive changes to enforcement around the time they introduced IFRS. We find no evidence of liquidity benefits in non-EU countries adopting IFRS even when they have strong legal systems or a strong track record of implementing regulation. To the extent that strong legal institutions and high regulatory quality are reasonable proxies for how countries enforce IFRS, our results are inconsistent with the view that mandatory IFRS reporting has capital-market benefits as long as the standards are (properly) enforced. Instead, our results point to concurrent enforcement changes as an important candidate for an omitted variable in prior IFRS studies and suggest that changes in reporting enforcement play a crucial role for the observed liquidity effects.

Consistent with this interpretation, we show liquidity increases for voluntary IFRS adopters around the time of the IFRS mandate, but only in those countries with concurrent enforcement changes. This evidence is inconsistent with the notion that mandatory IFRS adoption has had widespread comparability (or spillover) effects, as these effects should not be confined to firms in a select few countries. In addition, we analyze liquidity effects in countries where substantive enforcement changes occur after they adopted IFRS and in the case of Japan without a prior move to IFRS reporting. For these countries, the effects of IFRS and enforcement changes are 
potentially separable. We find that liquidity improves after substantive changes in enforcement but not after IFRS adoption.

In sum, our results support explanation (iii) and generally suggest that enforcement changes in a few countries play a critical role for the documented liquidity effects. This evidence does not automatically imply that IFRS play no role. It is possible that IFRS reporting was a precondition for the enforcement changes to take place or, alternatively, that the liquidity effects would have been smaller without IFRS adoption. The majority of our tests cannot rule out either possibility. However, the results for Japan show that (prior) IFRS adoption is not a necessary condition to obtain liquidity benefits around substantive enforcement changes. The sum of our results makes it unlikely that the change in accounting standards is the primary or even an important driver of the liquidity effects around IFRS adoption. Thus, the results say more than 'enforcement matters' for IFRS to have an effect. At a minimum, our findings should make researchers more careful about the empirical identification and about attributing observed capital-market effects to the change in accounting standards, i.e., to label them as "IFRS effects."

In closing, several caveats are in order. First, while our research design rules out many concerns about omitted variables and alternative explanations, we acknowledge that other changes to financial reporting (e.g., audit reforms) that are closely aligned with the concurrent enforcement changes could play into our findings. If such other factors exist, they do not alter the main message of this study - there still is a correlated omitted variable problem around IFRS adoption. But it implies that we cannot simply attribute the documented liquidity effects to enforcement changes either. Second, the treatment effects in this study are estimated for countries that have chosen to adopt IFRS and/or to change their financial reporting enforcement. Due to this selection, the estimated treatment effects might not be representative for other 
countries that have not yet elected to make such changes. Thus, our study does not advocate for policy changes in other countries. Third, our study focuses solely on market liquidity. We need more research to assess whether the results extend to other (capital-market) effects. However, using our identification strategy requires that the effects can be measured reliably over short intervals. This feature presents a major empirical challenge to extending the analyses of this study to other capital-market measures that are either more anticipatory in nature or adjust slowly. Finally, we note that our study does not analyze the costs of changing standards or enforcement, and hence is silent on the net effects of these regulatory initiatives. 


\section{Appendix: Details on substantive enforcement changes for select sample countries}

The information in this appendix is based on a survey that we sent out to the authority responsible for supervising compliance with accounting standards as well as the technical departments of PricewaterhouseCoopers in each EU country and, in a second survey, to all national regulators in the remaining sample countries. ${ }^{44}$ The survey specifically asks whether and when there has been a substantive change in enforcement with respect to financial reporting over the 2001 to 2009 period. ${ }^{45}$ The survey also asked a number of related questions designed to establish how substantive the enforcement change was, including when the current enforcement institution was set-up, whether listed firms have to file annual reports with the enforcement institution, what actions the enforcement institution has taken and if so, when the first action was taken, as well as what enforcement mechanism was in place before the change. When the response indicated changes in enforcement, we engaged in follow-up correspondence and interviews with the respondents. We also used public sources such as the annual reports of the regulators to clarify the extent and timing of the enforcement change and to obtain indications of enforcement activities that would be consistent with a substantive enforcement change. ${ }^{46}$ Ultimately, however, the coding of substantive enforcement changes also reflects our judgment based on the available information.

The survey was distributed electronically and as a hardcopy. We promised respondents anonymity and that we would not publish their answers. Hence, we can only provide a condensed summary in this appendix. For brevity, we limit the description of institutional changes to countries with a substantive change in enforcement over the 2001 to 2009 period (see also Table 1).

The respondents of all countries described in this appendix answered 'yes' to the following question:

"Would you say there has been a substantive change in the intensity of enforcement with respect to financial reporting in your country from 2001 to 2009?" To pinpoint the timing of the enforcement

44 Similar in spirit, Brown et al. (2013) also construct an enforcement index using public sources. But as their index is not focused on changes around IFRS adoption, we cannot use it for our purposes.

45 While we received answers from all EU member states, the response rate of the remaining countries is only about 30 percent. Notably, the U.S. Securities and Exchange Commission (SEC) does not answer questionnaire surveys and consequently we report ' $n$.a.' in Table 1 for the USA. The most significant regulatory reform in the U.S. over our sample period is the Sarbanes-Oxley Act of 2002 (SOX). SOX includes provisions on the compliance with accounting standards like stronger criminal penalties for manipulating financial statements, and the SEC likely has intensified enforcement activities in light of the corporate scandals of the early 2000s. However, unlike in the IFRS adopting countries, this substantial shift in enforcement occurred more gradually over an extended period of time, and is therefore ill suited for our research design. As a sensitivity check, we nevertheless code the U.S. as one of the countries with a substantive enforcement change (i.e., $\triangle E N F$ takes on the value of ' 1 ' beginning in September 2002, the introduction of the main provisions of SOX). This coding groups the U.S. together with Japan in Table 6, and does not alter our findings.

46 Specifically, we compare the answers to the annual reports of the local supervisory authorities, a report on enforcement mechanisms in Europe (FEE, 2001), and a survey conducted by the Committee of European Securities Regulators (CESR) on the supervisory powers in the EU (CESR, 2007a). In case of discrepancies, we contact the national securities regulator in an attempt to resolve the issue. 
change, we use the date that a country instigated a proactive comment and review process (or some other substantive procedure). Setting up a proactive comment and review process is itself material for countries that have not previously enforced disclosure regulation or only on a reactive basis. But it should be noted that it is generally only one component of the enforcement change and it is often accompanied by other elements such as an increase in penalties and more resources for the enforcement body. Moreover, the set of enforcement changes varies among countries (see Berger, 2010, for a discussion of the variation in enforcement within the EU).

\section{A1. Countries that bundled IFRS and substantive enforcement changes}

The IAS Regulation that mandates IFRS reporting for firms listed on regulated markets in the EU for fiscal years ending on or after December $31^{\text {st }}, 2005$, requires member states to take appropriate measures to ensure compliance with IFRS. Paragraph 16 of the IAS Regulation states: "A proper and rigorous enforcement regime is key to underpinning investors' confidence in financial markets. Member States, by virtue of Article 10 of the Treaty [establishing the European Community], are required to take appropriate measures to ensure compliance with international accounting standards. The Commission intends to liaise with Member States, notably through the Committee of European Securities Regulators (CESR), to develop a common approach to enforcement." Article 10 of the Treaty establishing the European Community states: "Member States shall take all appropriate measures, whether general or particular, to ensure fulfillment of the obligations arising out of this Treaty or resulting from action taken by the institutions of the Community." It follows that paragraph 16 of the IAS Regulation leaves EU member states with significant latitude in how to enforce compliance with IFRS (CESR, 2007b). Consistent with countries having substantial discretion, we find that only six EU countries made substantive changes to the enforcement of financial reporting upon IFRS adoption.

We note that in those six countries, the new enforcement activities were often explicitly tied to the release of the (first) annual reports under IFRS. As a consequence, IFRS adoption and the enforcement change are essentially bundled and cannot be separated, even when the date of the enforcement change deviates slightly from the official IFRS adoption date. Thus, we do not separately code the $\triangle E N F$ variable for those countries, but use $I F R S_{E U_{-} E N F}$ instead.

\section{A1.1. Finland (enforcement date: 2005 Q1)}

On January 1, 2005, the Financial Supervisory Authority (FSA) in Finland instituted a proactive review and comment procedure for listed firms. There were no enforcement activities with regard to the compliance with accounting standards or regulation before that date. The first sanctions imposed on firms 
were: (i) publically disclosed violations in 2006, (ii) restatements of financial statements in 2007, and (iii) publicly issued warnings in 2008.

\section{A1.2. Germany (2005 Q4)}

The Bundesanstalt für Finanzdienstleistungsaufsicht (BaFin) acts as the financial regulatory authority for Germany. However, the Financial Reporting Enforcement Panel (FREP), a private organization, conducts the examinations that establish whether listed firms are in compliance with accounting standards. The FREP was set up on July 1, 2005 and began actively monitoring compliance in the fourth quarter of 2005. There was no proactive enforcement of compliance with accounting standards prior to that date. Formally, it is voluntary for listed firms to cooperate with the FREP, which has no official powers. However, in case of non-compliance, the FREP can refer cases to the BaFin, which then takes action. In each of the first two years of its existence, the FREP reviewed about 130 firms (15\% of German listed firms), and in approximately one third of these cases found errors and disclosed them, which led to significant market reactions (see Ernstberger et al., 2012, for details). In 2006, the first sanctions were imposed on firms by the public disclosure of errors. In addition to the aforementioned enforcement changes to support compliance with IFRS, Germany also elected to tighten audit regulation in 2005 making the German changes concurrent to IFRS adoption more comprehensive than most enforcement changes in other EU countries.

\section{A1.3. Iceland (2005 Q3)}

Iceland technically is not a member of the EU, but adopted most EU regulations in the process of joining the EU single market. The Registrar of Annual Accounts (RAA) is responsible for the enforcement of compliance with accounting standards. The RAA dedicated one staff member to carry out the reviews beginning in September 2005, and another staff member in August 2006. There are less than ten firms listed on the Iceland Stock Exchange and hence, each staff member is responsible for about five issuers. Prior to IFRS adoption the RAA would only perform a limited probe. The first sanctions were imposed in 2007, and include: (i) public disclosure of violations, (ii) restatements of financial statements, and (iii) changes to financial statements going forward.

\section{A1.4. Netherlands (2005 Q4)}

Although the Authority for Financial Markets (AFM) was not formally set up until 2006, a proactive comment and review process began in the last quarter of 2005. The Supervisory Financial Reporting Act (Wet Toezicht Finaniele Verslaggeving; Wtfv), which gives the AFM the statutory task of reviewing financial statements, was originally scheduled to enter into force on November $1^{\text {st }}, 2005$, but was later postponed until December $31^{\text {st }}, 2006$. Despite this lack of statutory support the AFM began to proactively 
review financial reports (on a voluntary basis) upon IFRS adoption in 2005. In each of the first two years of its existence, the AFM reviewed around 30 firms (about 10\% of publicly listed firms). The first sanctions were imposed in 2007, and include: (i) public disclosure of violations, (ii) restatements of financial statements, and (iii) changes to financial statements going forward.

\section{A1.5. Norway (2005 Q4)}

Norway technically is not a member of the EU, but adopted most EU regulations in the process of joining the EU single market. The Financial Supervisory Authority of Norway (FSAN) was set up on January 1, 2005, and listed firms were required to submit annual reports to FSAN from October 2005 on (Law no. 81, December 10, 2004). Before that date, the Oslo Stock Exchange was responsible for enforcement, but there existed no formal proactive review process. On January 19, 2005, the FSAN sent a letter to all listed firms, proclaiming that enforcement would be stricter going forward and provided a list of potential sanctions. In 2006, the FSAN reviewed around 35 firms (more than $10 \%$ of publicly listed firms). The first sanctions after the shift were imposed in 2006, and included: (i) public disclosure of errors, and (ii) changes in accounting practices going forward. In 2007, restatements were required for the first time, followed by criminal sanctions and monetary fines in 2008 and 2009.

\section{A1.6. United Kingdom (2005 Q2)}

In the U.K., the enforcement change occurred in two steps. First, the Financial Reporting Review Panel (FRRP) officially switched from performing only reactive reviews to proactive reviews in the year prior to IFRS adoption, i.e., during the first quarter of 2004 (Companies Act 2004 - Audit, Investigations and Community Enterprise). The reactive approach involved acting on cases brought to the FRRP's attention, for instance, via complaints made by individuals, companies, or the media. Hence, under the reactive approach the FRRP had little choice in the cases it reviewed and only limited control over the matters it considered (see Brown and Tarca, 2007, for details). During the initial phase of proactive reviews, the FRRP adopted a so-called "broad-based" approach in selecting financial statements for review. In a second step, the approach was developed further, also in preparation of IFRS adoption. By April 2005, the FRRP had fully implemented a risk-based and random sampling method to select companies, industries and reporting areas that its experts considered particularly important or problematic (in line with the recommendations in CESR Standard No. 1). At the same time, the supervisory powers and resources of the FRRP were substantially expanded. The increased powers enabled the FRRP to more effectively liaise with other regulators and also extend its remit to interim accounts. Consistent with this timing, our survey and follow-up discussions with regulators and experts identify the second quarter of 2005 as the substantive change in reporting enforcement. Even though the implementation of proactive 
reviews began earlier, the enhanced sampling techniques and increased powers coincided with IFRS adoption. Thus, we classify the U.K. as bundled because all enforcement changes took place relatively close to IFRS adoption and several of them were directly tied to the pending IFRS mandate. ${ }^{47}$

On a yearly basis, the FRRP proactively reviews between 200 and 300 interim or annual financial reports (about $15 \%$ of publicly listed firms). The number of actions varies from year to year with a maximum of 94 in 2006/2007. The most common sanction is demanding corrections to future financial statements, which companies generally undertake voluntarily. However, in every year since the FRRP switched to proactive reviews, it has publicly disclosed errors and imposed restatements of firms' financial statements.

\section{A2. Countries that did not bundle IFRS and substantive enforcement changes}

We identify ten sample countries with a substantive change in enforcement independent of IFRS, six of which are EU member states, and eight also adopted IFRS at some point during our sample period. It is worth noting that the enforcement changes in the EU generally follow the recommendations in CESR Standard No. 1, and later the requirements of the TPD. As a result, the changes are relatively homogenous. The changes in Hong Kong and Japan are substantive, but distinct from the EU changes, as explained below. The differential timing of IFRS adoption and enforcement changes allows us to separately code up the IFRS and $\triangle E N F$ variables in our analyses.

\section{A2.1. Chile (non-EU country; 2009 Q2)}

The Superintendencia de Valores y Seguros (SVS) is responsible for the enforcement of compliance with disclosure requirements. A comment and review process has existed for the entire sample period (with administrative fines, required restatements, and the public disclosure of violations occurring before 2001), but it was substantially strengthened in June 2009 in anticipation of IFRS adoption. The first criminal sanctions under the new regime were imposed in 2011.

\section{A2.2. Estonia (EU member; 2003 Q4)}

The Estonian Financial Supervision Authority (EFSA) dedicated one staff member to the enforcement of compliance with accounting standards in October 2003. The hiring was in response to the

47 To gauge the sensitivity of our results to the Q2/2005 date and our choice of bundling the enforcement change with IFRS adoption, we first re-run the analyses excluding all U.K. firms from the sample and find similar results to those reported in the main text. Second, we separate the coding of the IFRS and $\triangle E N F$ variables for the U.K. and instead treat the U.K. like the other EU countries without concurrent enforcement changes (see Table 6, Model 1). In this specification, $\triangle E N F_{E U}\left(I F R S_{E U_{-} E N F}\right)$ becomes (remains) significantly negative, but contrary to the main tests, the magnitude of the enforcement coefficient is now larger than the IFRS coefficient for the remaining four bundled countries. This evidence is consistent with Q2/2005 marking an important enforcement shift in the U.K. and our interpretation that enforcement changes play a major role in the findings. 
requirement in the IAS Regulation and in anticipation of IFRS reporting, but occurred more than a year before the IFRS mandate took effect. Less than 20 firms are listed on the Tallinn Stock Exchange. In 2003, the first sanctions were imposed including: (i) public disclosure of errors, and (ii) restatements of financial statement information.

\section{A2.3. Hong Kong (non-EU country; adopted IFRS; 2008 Q3)}

The Financial Reporting Council (FRC) was established on December 1, 2006 (FRC Ordinance, Chapter 588). Prior to that date the system was built on self-regulation with the Hong Kong Institute of Certified Public Accountants (HKICPA) responsible for enforcing compliance with accounting standards. In the first years of its existence, the FRC would only act reactively to complaints. The switch towards a proactive comments and review process did not occur until July 16, 2008. The proactive reviews focus on financial statements with modified audit opinions. In the last year before the regime change, the FRC only received six complaints. In 2009, 129 financial statements were proactively reviewed and 19 complaints were received. Hence, the case of Hong Kong is similar to the U.K. in that it switched from reactively to proactively reviewing financial reports, but in Hong Kong the switch occurred years after IFRS adoption.

The first sanctions were imposed in 2009, when the FRC published a report on its first investigation. The report was forwarded to HKICPA, which in turn issued a "Disapproval Letter" to both the auditor and the engagement director under investigation, advising them to "exercise due care and to act with proper regard to the legal and professional obligations expected of them". Even though the enforcement changes in Hong Kong are considered substantive, the exact procedures and sanctions are distinct from the changes in the EU.

\section{A2.4. Hungary (EU member; 2008 Q1)}

The Hungarian Financial Supervisory Authority (HFSA) is responsible for enforcing compliance with accounting standards. The HFSA set up a team dedicated to proactively reviewing financial statements at the beginning of 2008. No enforcement of compliance with accounting standards took place prior to that date. The first sanctions were imposed in the first half of 2009, and included: (i) restatements of financial statement information, and (ii) changes to financial statements going forward.

\section{A2.5. Ireland (EU member; 2007 Q3)}

The Irish Audit and Accounting Supervisory Authority (IAASA) was incorporated in December 2005. However, it was not given the responsibility to enforce financial reporting regulation until June 2007. Beginning in the third quarter of 2007, the IAASA started to review half-yearly reports, and the first annual financial reports under the IAASA's remit were those with a fiscal year beginning after 
January 20, 2007. No comments and review process existed before that date, and consequently no sanctions were imposed on firms prior to the shift. The first sanctions occurred in 2008 when the IAASA directed an issuer to restate its financial statements.

\section{A2.6. Japan (non-EU country; did not adopt IFRS; 2005 Q3)}

On November 16, 2004, the Financial Service Authority in Japan (FSAJ) announced a series of measures intended to enhance enforcement of disclosure regulation. The trigger for the shift was a series of high-profile corporate scandals involving disclosure misconduct. The changes were designed to increase confidence in the Japanese disclosure system. The action plan consisted of four measures: ${ }^{48}$ (i) an enhanced framework for reviewing statutory disclosure documents (e.g., annual reports), (ii) improved auditor oversight, (iii) further development of the disclosure system including the requirement of auditors to certify the effectiveness of firms' internal controls and the expansion of the administrative civil penalty system to include breaches of disclosure requirements, and (iv) amendments to the stock exchanges' listing rules to ensure appropriate and timely disclosure of corporate information.

A central component of the plan was the transfer of the authority to carry out inspections of statutory disclosure documents from the Kanto Local Finance Bureau (KLFB) to the Securities and Exchange Surveillance Commission (SESC) effective in July 2005. The transfer of responsibility was a turning point because the KLFB had exerted little effort in the enforcement of disclosure regulation before that date. Overall, the changes that occurred in Japan in 2005 strengthened the enforcement of compliance with accounting standards and other disclosure regulation. However, the case of Japan is distinct from the changes in the EU and in Hong Kong in that it also includes substantive changes to audit regulation.

\section{A2.7. Lithuania (EU member; 2007 Q4)}

The Securities Commission of the Republic of Lithuania (LSC) was set up in February 2007, but did not institute a comment and review process until November 2007. The procedures for selecting and reviewing financial statements closely follow the principles laid out in the CESR Standard No. 1. The LSC can issue pecuniary penalties. Prior to 2007, Lithuania did have a formal enforcement regime, but no major enforcement actions were taken. The first sanctions under the new regime were imposed in 2008, and included: (i) public disclosure of violations, and (ii) restatements of financial statement information.

\section{A2.8. Luxembourg (EU member; 2009 Q4)}

The Commission de Surveillance du Secteur Financier (CSSF) was set-up in 1945, but did not implement a proactive comment and review process until the fourth quarter of 2009. In 2010, CSSF

48 For details see the Financial Services Agency’s website: http://www.fsa.go.jp/news/newse/e20041116-1.html 
reviewed more than one third of the listed firms, of which nearly $10 \%$ were subject to an in-depth review. The CSSF first required a restatement in 2011.

\section{A2.9. Sweden (EU member; 2007 Q3)}

The Swedish Financial Supervisory Authority (SFSA) has been responsible for enforcing compliance with accounting standards since July 2007. The stock exchanges performed (reactive) reviews of annual accounts before that date, but the SFSA implemented a stricter review of annual and interim reports. The first sanctions under the new regime were imposed in 2008, and included: (i) public disclosure of violations, and (ii) changes to financial statements going forward.

A2.10. Turkey (non-EU member; 2008 Q1)

The Capital Market's Board of Turkey (CMBT) has been responsible of enforcing compliance with accounting standards since 1999; however, a risk-based proactive review process was not implemented until the first quarter of 2008. The changes in 2008 were implemented with the assistance of AFM, the Dutch enforcement institution, and therefore closely follow the recommendations of CESR in the EU. Two main components were implemented: (i) a risk based supervision system, and (ii) a new Financial Reporting Supervision Group within the CMBT to increase the effectiveness of the enforcement of financial reporting requirements. In addition the CMBT staff received extensive technical training on IFRS. 


\section{References}

Ahmed, A., Neel, M., Wang, D., 2013. Does mandatory adoption of IFRS improve accounting quality? Preliminary evidence. Contemporary Accounting Research, forthcoming.

Amihud, Y., 2002. Illiquidity and stock returns: cross-section and time-series effects. Journal of Financial Markets 5, 31-56.

Armstrong, C., Barth, M., Jagolinzer, A., Riedl, E., 2010. Market reaction to the adoption of IFRS in Europe. The Accounting Review 85, 31-61.

Atwood, T., Drake, M., Myers, J., Myers, L., 2011. Do earnings reported under IFRS tell us more about future earnings and cash flows? Journal of Accounting and Public Policy 30, $103-121$.

Bae, K., Tan, H., Welker, M., 2008. International GAAP differences: the impact on foreign analysts. The Accounting Review 83, 593-628.

Ball, R., 2001. Infrastructure requirements of an economically efficient system of public financial reporting and disclosure, in: Litan, R., Herring, R. (Eds.), Brookings-Wharton Papers on Financial Services. Brookings Institution Press, Washington, pp. 127-169.

Ball, R., Kothari, S. P., Robin, A., 2000. The effect of international institutional factors of properties of accounting earnings. Journal of Accounting and Economics 29, 1-51.

Ball, R., Robin, A., Wu, J., 2003. Incentives versus standards: properties of accounting income in four East Asian countries. Journal of Accounting and Economics 36, 235-270.

Barth, M., 2006. Research, standard setting, and global financial reporting. Foundations and Trends in Accounting 1, 71-165.

Barth, M., Landsman, W., Lang, M., Williams, C., 2012. Are IFRS-based and US GAAP-based accounting amounts comparable? Journal of Accounting and Economics 54, 68-93.

Bekaert, G., Harvey, C., Lundblad, C., 2007. Liquidity and expected returns: lessons from emerging markets. Review of Financial Studies 20, 1783-1831.

Beneish, M., Miller, B., Yohn, T., 2010. IFRS adoption and cross-border investment in equity and debt markets. Working paper. Indiana University.

Berger, A., 2010. The development and status of enforcement in the European Union. Accounting in Europe 7, 15-35.

Bertrand, M., Duflo, E., Mullainathan, S., 2004. How much should we trust differences-indifferences estimates? Quarterly Journal of Economics 119, 249-275.

Beuselinck, C., Joos, P., Khurana, I., Van der Meulen, S., 2009. Mandatory IFRS reporting and stock price informativeness. Working paper. Tilburg University and University of Missouri at Columbia.

Bhattacharya, U., Daouk, H., 2002. The world price of insider trading. Journal of Finance 57, 75-108.

Brown, P., Preiato, J., Tarca, A., 2013. Mandatory adoption of IFRS and analysts' forecasts: how much does enforcement matter? Working paper. University of Western Australia.

Brown, P., Tarca, A., 2007. Achieving high quality, comparable financial reporting: a review of independent enforcement bodies in Australia and the United Kingdom. Abacus 43, 438-473. 
Brüggemann, U., Daske, H., Homburg, C., Pope, P., 2012. How do individual investors react to global IFRS adoption? Working paper. University of Mannheim, University of Cologne, and Cass Business School.

Brüggemann, U., Hitz, J., Sellhorn, T., 2013. Intended and unintended consequences of mandatory IFRS adoption: a review of extant evidence and suggestions for future research. European Accounting Review 22, 1-37.

Burgstahler, D., Hail, L., Leuz, C., 2006. The importance of reporting incentives: earnings management in European private and public firms. The Accounting Review 81, 983-1016.

Bushman, R., Piotroski, J., Smith, A., 2005. Insider trading restrictions and analysts' incentives to follow firms. Journal of Finance 60, 35-66.

Byard, D., Li, Y., Yu, Y., 2011. The effect of mandatory IFRS adoption on financial analysts' information environment. Journal of Accounting Research 49, 69-96.

Campbell, J., 1996. Understanding risk and return. Journal of Political Economy 104, 298-345.

Capkun, V., Collins, D., Jeanjean, T., 2011. Does adoption of IAS/IFRS deter earnings management? Working paper. HEC Paris, University of Iowa, and ESSEC Business School.

CESR, 2007a. Report on CESR members' powers under the Market Abuse Directive and its implementing measures. \#CESR/07-380, Committee of European Securities Regulators, Paris.

CESR, 2007b. CESR's review of the implementation and enforcement of IFRS in the EU. \#CESR/07-352, Committee of European Securities Regulators, Paris.

Chordia, T., Roll, R., Subrahmanyam, A., 2000. Co-movements in bid-ask spreads and market depth. Financial Analysts Journal 56, 23-27.

Christensen, H., Hail, L., Leuz, C., 2013a. Capital-market effects of securities regulation: hysteresis, implementation, and enforcement. Working paper. University of Chicago and University of Pennsylvania.

Christensen, H., Hail, L., Leuz, C., 2013b. Proper inferences or a market for excuses? The capital-market effects of mandatory IFRS adoption. Working paper. University of Chicago and University of Pennsylvania.

Christensen, H., Lee, E., Walker, M., 2008. Incentives or standards: what determines accounting quality changes around IFRS adoption? Working paper. University of Manchester.

CRA, 2009. Evaluation of the economic impacts of the Financial Services Action Plan. Final report prepared for the European Commission, CRA International, London.

Cumming, D., Johan, S., Li, D., 2011. Exchange trading rules and stock market liquidity. Journal of Financial Economics 99, 651-671.

Daske, H., Hail, L., Leuz, C., Verdi, R., 2008. Mandatory IFRS reporting around the world: early evidence on the economic consequences. Journal of Accounting Research 46, 1085-1142.

Daske, H., Hail, L., Leuz, C., Verdi, R., 2013. Adopting a label: heterogeneity in the economic consequences around IAS/IFRS adoptions. Journal of Accounting Research 51, 495-547.

DeFond, M., Hu, X., Hung, M., Li, S., 2011. The impact of mandatory IFRS adoption on foreign mutual fund ownership: the role of comparability. Journal of Accounting and Economics 51, 240-258.

Diamond, D., Verrecchia, R., 1991. Disclosure, liquidity, and the cost of capital. Journal of Finance 46, 1325-1359. 
Djankov, S., La Porta, R., Lopez-de-Silanes, F., Shleifer, A., 2008. The law and economics of self-dealing. Journal of Financial Economics 88, 430-465.

Ernstberger, J., Hitz, J., Stich, M., 2012. Enforcement of accounting standards in Europe: capitalmarket-based evidence for the two-tier mechanism in Germany. European Accounting Review 21, 253-281.

FEE, 2001. Enforcement mechanisms in Europe: a preliminary investigation of oversight systems. Fédération des Experts Comptables Européens, Brussels.

Florou, A., Kosi, U., 2013. Does mandatory IFRS adoption facilitate debt financing? Working paper. King's College and Humboldt University.

FRRP, 2007. Financial Reporting Review Panel: activity report 2007. Financial Reporting Review Panel, London.

FSAP, 1999. Implementing the framework for financial markets: action plan, European Commission. Communication No. 232, May 11, 1999, Brussels.

Gebhardt, G., Novotny-Farkas, Z., 2011. Mandatory IFRS adoption and accounting quality of European banks. Journal of Business Finance and Accounting 38, 289-333.

Glosten, L., Harris, L., 1988. Estimating the components of the bid/ask spread. Journal of Financial Economics 21, 123-142.

Glosten, L., Milgrom, P., 1985. Bid, ask and transaction prices in a specialist market with heterogeneously informed traders. Journal of Financial Economics 14, 71-100.

Gordon, E., Jorgensen, B., Linthicum, C., 2009. Could IFRS replace U.S. GAAP? A comparison of earnings attributes and informativeness in the U.S. market. Working paper. Temple University, University of Colorado, and University of Texas at San Antonio.

Hail, L., Leuz, C., 2007. Capital market effects of mandatory IFRS reporting in the EU: empirical evidence. Report made available by the Netherlands Authority for the Financial Markets (AFM), http://www.afm.nl/corporate/default.ashx?DocumentId=10519.

Hail, L., Leuz, C., Wysocki, P., 2010. Global accounting convergence and the potential adoption of IFRS by the U.S. (part I): conceptual underpinnings and economic analysis. Accounting Horizons 24, 355-394.

Horton, J., Serafeim, G., Serafeim, I., 2013. Does mandatory IFRS adoption improve the information environment? Contemporary Accounting Research 30, 388-423.

ICAEW, 2007. EU Implementation of IFRS and the Fair Value Directive: a report for the European Commission. The Institute of Chartered Accountants in England and Wales, London.

Kalemli-Ozcan, S., Papaioannou, E., Peydró, J., 2010. What lies beneath the Euro's effect on financial integration? Currency risk, legal harmonization, or trade? Journal of International Economics 81, 75-88.

Kalemli-Ozcan, S., Papaioannou, E., Peydró, J., 2013. Financial regulation, financial globalization, and the synchronization of economic activity. Journal of Finance 68, 11791228.

Kaufmann, D., Kraay, A., Mastruzzi, M., 2009. Governance matters VIII: governance indicators for 1996-2008. World Bank Policy Research, Washington, D.C.

Khurana, I., Michas, P., 2011. Mandatory IFRS adoption and the U.S. home bias. Accounting Horizons 25, 729-753. 
Landsman, W., Maydew, E., Thornock, J., 2012. The information content of annual earnings announcements and mandatory adoption of IFRS. Journal of Accounting and Economics 53, $34-54$.

Lang, M., Lins, K., Maffett, M., 2012. Transparency, liquidity and valuation: international evidence on when transparency matters most. Journal of Accounting Research 50, 729-774.

La Porta, R., Lopez-de-Silanes, F., Shleifer, A., 2006. What works in securities laws? Journal of Finance 61,1-32.

La Porta, R., Lopez-de-Silanes, F., Shleifer, A., Vishny, R., 1997. Legal determinants of external finance. Journal of Finance 52, 1131-1150.

Lesmond, D., 2005. Liquidity of emerging markets. Journal of Financial Economics 77, 411452.

Lesmond, D., Ogden, J., Trzcinka, C., 1999. A new estimate of transaction costs. Review of Financial Studies 12, 1113-1141.

Leuz, C., 2007, Was the Sarbanes-Oxley Act of 2002 really this costly? A discussion of evidence from event returns and going-private decisions, Journal of Accounting and Economics 44, $146-165$.

Leuz, C., Verrecchia, R., 2000. The economic consequences of increased disclosure. Journal of Accounting Research 38, 91-124.

Li, S., 2010. Does mandatory adoption of International Financial Reporting Standards in the European Union reduce the cost of equity capital? The Accounting Review 85, 607-636.

Petersen, M., 2009. Estimating standard errors in finance panel data sets: comparing approaches. Review of Financial Studies 22, 435-480.

Pownall, G., Wieczynska, M., 2012. Deviations from the mandatory adoption of IFRS in the European Union: incentives, standards, and compliance. Working paper. Emory University.

Shima, K., Gordon, E., 2011. IFRS and the regulatory environment: the case of U.S. investor allocation choice. Journal of Accounting and Public Policy 30, 481-500.

Soderstrom, N., Sun, K., 2007. IFRS adoption and accounting quality: a review. European Accounting Review 16, 675-702.

Stoll, H., 1978. The supply of dealer services in securities markets. Journal of Finance 33, 11331151.

Tan, H., Wang, S., Welker, M., 2011. Analyst following and forecast accuracy after mandated IFRS adoptions. Journal of Accounting Research 49, 1307-1357.

Venkatesh, P., Chiang, R., 1986. Information asymmetry and the dealer's bid-ask spread: a case study of earnings and dividend announcements. Journal of Finance 41, 1089-1102.

Verrecchia, R., 2001. Essays on disclosure. Journal of Accounting and Economics 32, 97-180. 


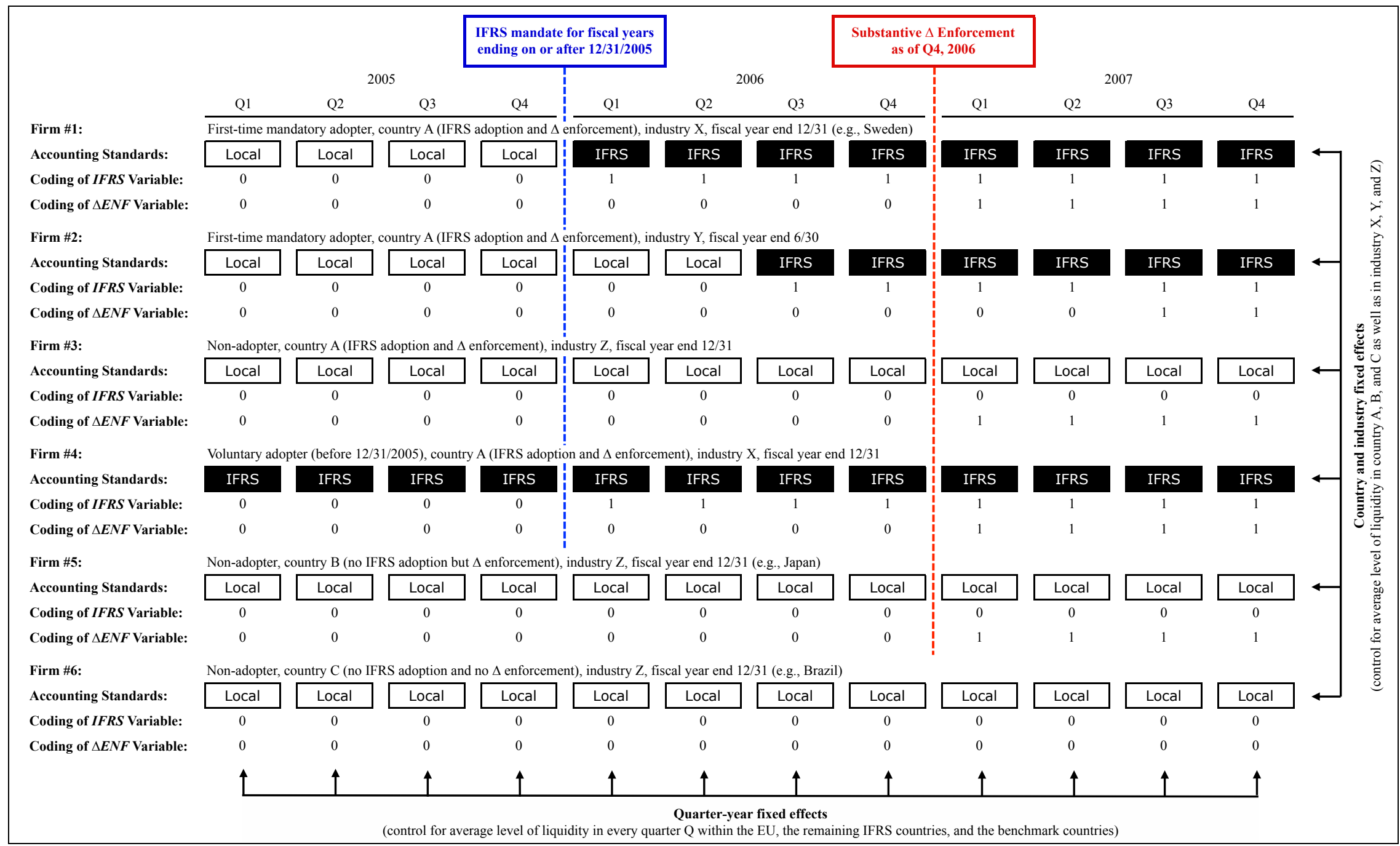

The figure illustrates our identification strategy for the two main variables of interest, IFRS and $\triangle E N F$, using generic firm examples. IFRS is a binary indicator variable for firm-quarters with IFRS reporting that takes on the value of ' 1 ' beginning in the calendar quarter following the first fiscal-year end after IFRS became mandatory. For instance, firm \#2 with a fiscal year end in June is required to report under IFRS after 12/31/2005 and hence, the IFRS variable switches to ' 1 ' in Q3 of 2006. Firm \#3 does not fall under the IFRS mandate, e.g., because it only prepares legal-entity but no consolidated accounts. Firm \#4 already reported under IFRS before 2005. To test for additional liquidity effects as IFRS become mandatory, the IFRS variable switches to ' 1 ' in Q1 of $2006 . \Delta E N F$ is a binary indicator variable that takes on the value of ' 1 ' beginning in the calendar quarter following the first fiscal-year end after a substantive change $(\Delta)$ in enforcement took effect. For instance, firm \#2's annual reports are subject to increased scrutiny by the local supervisory authority after Q4 in 2006 and hence, the $\triangle E N F$ variable switches to ' 1 ' in Q3 of 2007 when the next annual report becomes available. The resulting variation in IFRS and $\triangle E N F$ (across firms and over time) allows us to introduce fixed effects for each country (and industry) as well as for every quarter of our sample period for EU, the remaining IFRS, and the benchmark countries, separately. The latter implies that the model includes three separate and completely flexible quarterly time trends. 
Figure 2: Time-Series Variation of Mandatory IFRS Adoption and Substantive Enforcement Changes

Panel A: Time-Series Pattern of Mandatory IFRS Adoption

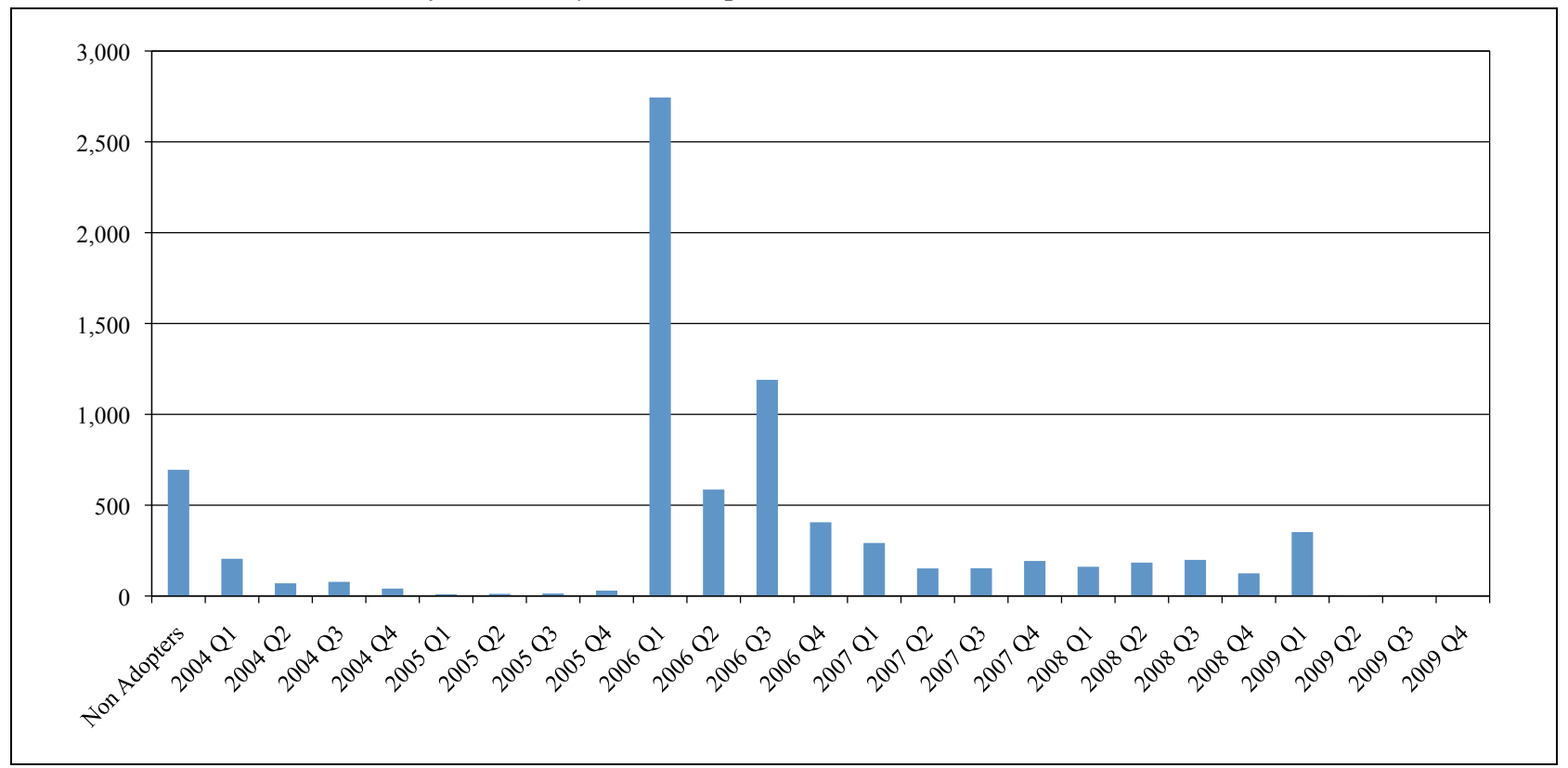

Panel B: Time-Series Pattern of Substantive Enforcement Changes

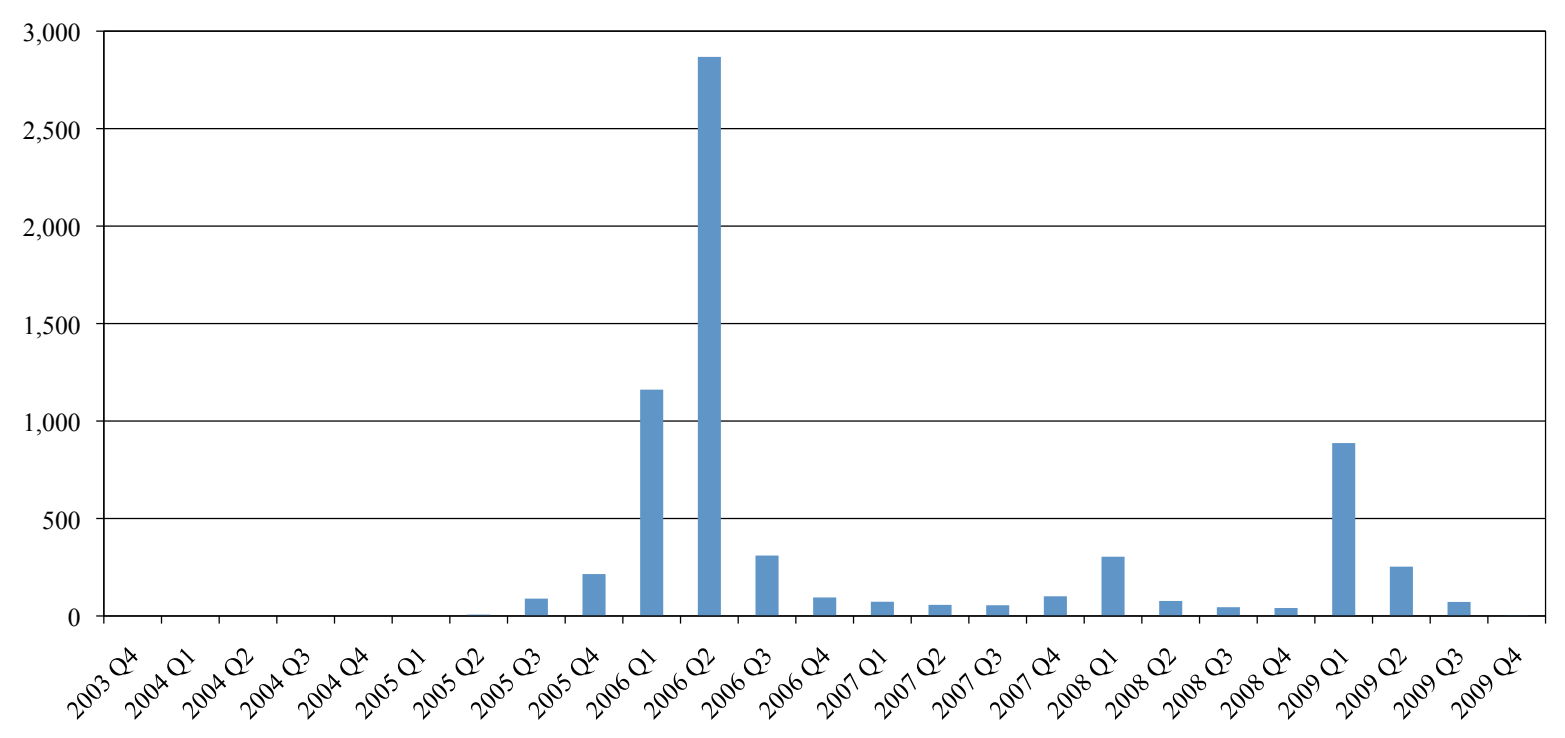

The figure illustrates the time-series variation in mandatory IFRS adoption (Panel A) and substantive enforcement changes (Panel B), which we use for our identification strategy. We identify substantive enforcement changes (e.g., the initiation of a proactive review process of financial statement information by the local supervisory authority) by conducting a survey of national regulators and audit firms and based on publicly available sources (see the Appendix). In Panel A, the sample consists of all firms from 35 IFRS adoption countries (EU and non-EU) over the 2001 to 2009 period. We determine the beginning of mandatory IFRS reporting as the calendar quarter immediately following the fiscal-year end after the IFRS mandate took effect. In Panel B, the sample comprises all firms from 16 (IFRS and non-IFRS) countries with substantive enforcement changes over the 2001 to 2009 period. We determine the initiation of the enforcement changes as the calendar quarter immediately following the first fiscal-year end after the local supervisory authority had instituted the new procedures (e.g., initiated a proactive review process). In both panels, we use the bid-ask spread sample as basis, and only plot the first IFRS or enforcement occurrence per firm. See also Figure 1 for further details on the coding of the IFRS and $\triangle E N F$ variables. 


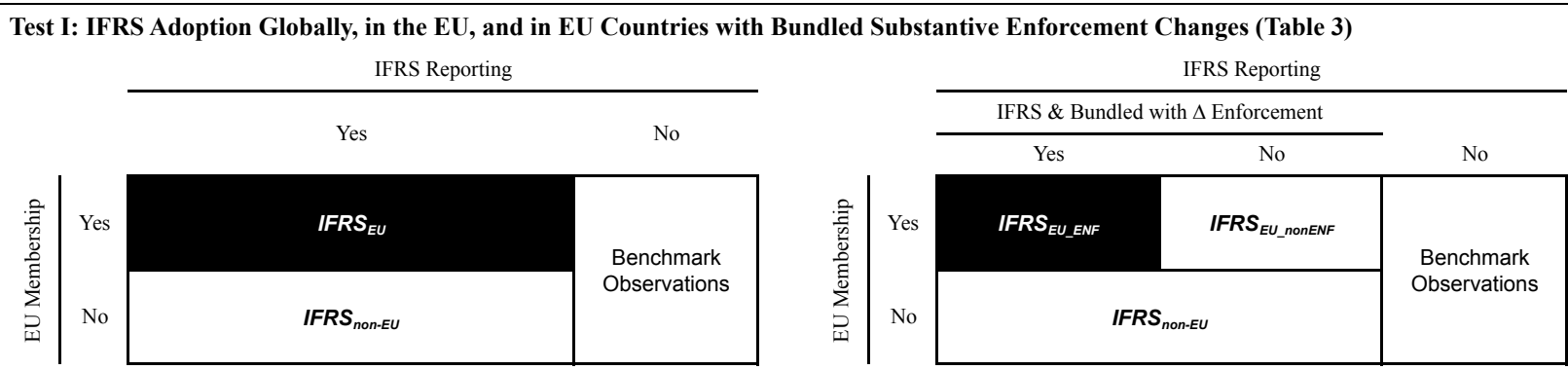

Test II: IFRS Adoption Conditional on Regulatory Quality and Substantive Changes in Enforcement (Table 4)
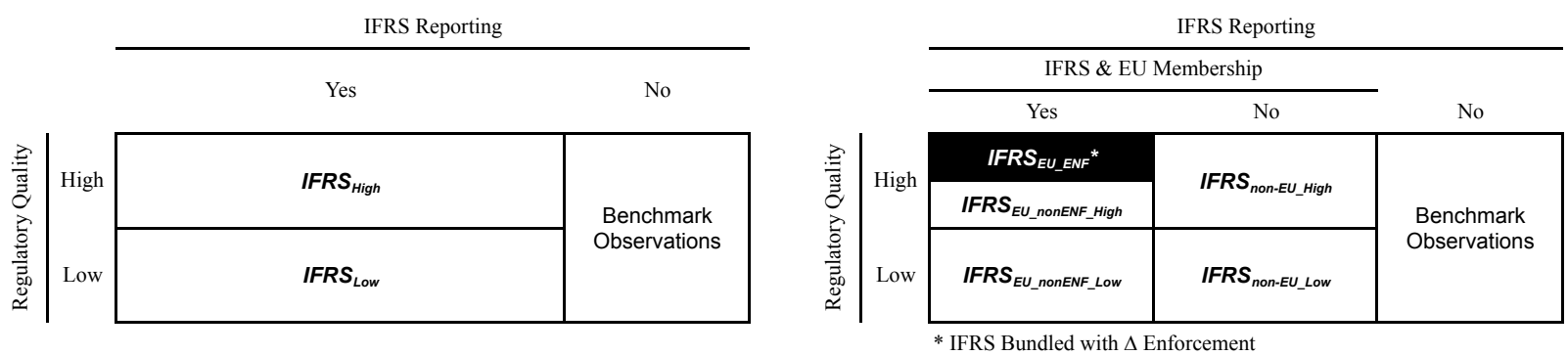

Test III: IFRS Adoption with Bundled Substantive Enforcement Changes Across Voluntary and Mandatory IFRS Adopters (Table 5)

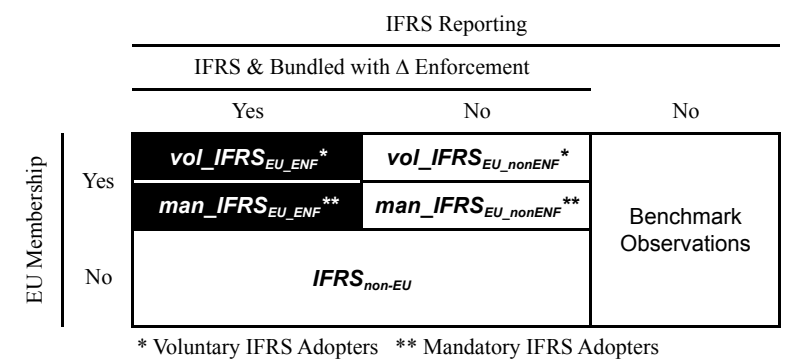

Test IV: Separating the Liquidity Effects of IFRS Adoption and Substantive Changes in Enforcement (Table 6)
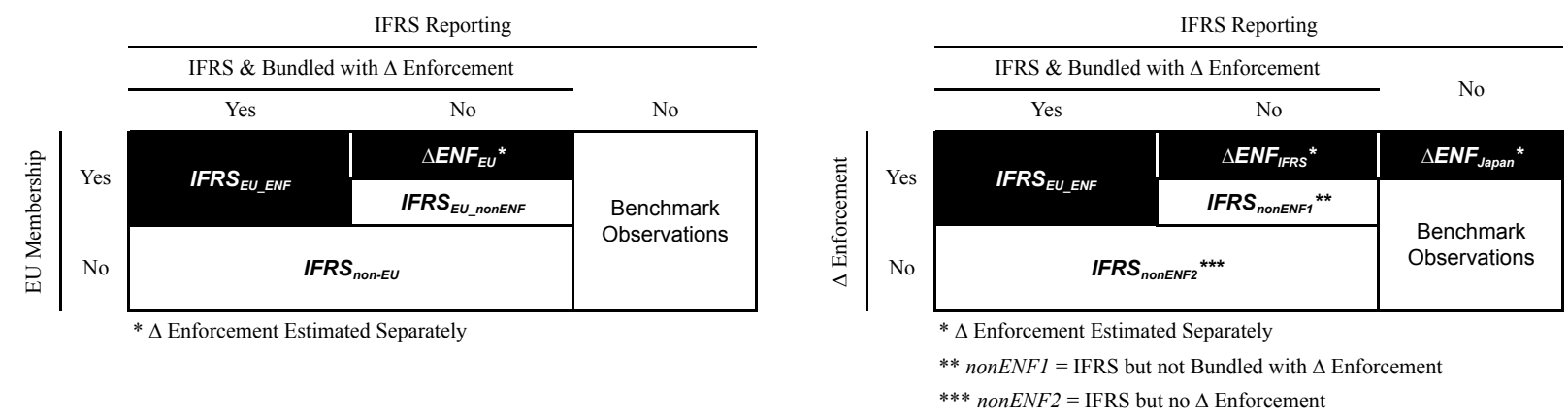

Prediction if substantive enforcement changes have positive effect on liquidity.

The figure illustrates our research strategy to disentangle the liquidity effects of mandatory IFRS adoption and substantive enforcement changes. For each empirical test, we partition the sample into various subsets (represented by a box containing the respective regression coefficient). We utilize four main sources of variation: (i) whether firms in a country are subject to IFRS reporting (IFRS/Benchmark Observations), (ii) membership in the EU (EU/non-EU), (iii) whether IFRS adoption is bundled with a substantive change $(\Delta)$ in enforcement (ENF/nonENF), and (iv) a country's regulatory quality (High/Low). In some analyses we further distinguish between firms that voluntarily adopted IFRS and first-time mandatory adopters ( $\mathrm{vol} / \mathrm{man})$, we separately estimate the liquidity effects of the (unbundled) substantive enforcement changes $(\triangle E N F)$, and we split the IFRS countries into countries with and without (unbundled) substantive enforcement changes over the sample period (nonENF1/nonENF2). The figure also indicates for which subset of observations we predict an increase in liquidity under the alternative hypothesis that substantive enforcement changes have an effect on liquidity. 
Table 1: Sample Composition, Institutional Variables, and Variable Coding by Country

Panel A: Number of Observations and Institutional Variables

\begin{tabular}{|c|c|c|c|c|c|}
\hline \multirow[b]{2}{*}{ Country } & \multirow{2}{*}{$\begin{array}{c}\text { Number of } \\
\text { Observations } \\
\text { (Bid-Ask } \\
\text { Spreads) }\end{array}$} & \multicolumn{3}{|c|}{ Institutional Variables (Raw Values) } & \multirow{2}{*}{$\begin{array}{l}\text { Number of } \\
\text { Voluntary IFRS } \\
\text { Observations } \\
\text { (Table 5) }\end{array}$} \\
\hline & & $\begin{array}{c}\text { Adoption of } \\
\text { Mandatory IFRS } \\
\text { Reporting (Date) }\end{array}$ & $\begin{array}{c}\text { Substantive } \Delta \\
\text { Enforcement 2001- } \\
2009(\mathrm{No} / \text { Yes, Date })\end{array}$ & $\begin{array}{l}\text { Regulatory } \\
\text { Quality } 2003 \\
\text { (Index) }\end{array}$ & \\
\hline \multicolumn{6}{|c|}{ European Union Countries $\left(I F R S_{E U}\right)$ : } \\
\hline Austria & 1,201 & $12 / 31 / 05$ & No & 1.52 & 816 \\
\hline Belgium & 3,250 & $12 / 31 / 05$ & No & 1.36 & 707 \\
\hline Czech Republic & 156 & $12 / 31 / 05$ & No & 1.12 & 72 \\
\hline Denmark & 4,802 & $12 / 31 / 05$ & No & 1.79 & 657 \\
\hline Estonia & 146 & $12 / 31 / 05$ & Yes (2003 Q4) & 1.40 & 0 \\
\hline Finland & 4,056 & $12 / 31 / 05$ & Yes (2005 Q1) & 1.90 & 205 \\
\hline France & 15,817 & $12 / 31 / 05$ & No & 1.18 & 1,101 \\
\hline Germany & 8,296 & $12 / 31 / 05$ & Yes (2005 Q4) & 1.51 & 3,439 \\
\hline Greece & n.a. & $12 / 31 / 05$ & No & 1.01 & 0 \\
\hline Hungary & 674 & $12 / 31 / 05$ & Yes (2008 Q1) & 1.08 & 342 \\
\hline Iceland & 89 & $12 / 31 / 05$ & Yes (2005 Q3) & 1.67 & 0 \\
\hline Ireland & 629 & $12 / 31 / 05$ & Yes (2007 Q3) & 1.66 & 0 \\
\hline Italy & 7,569 & $12 / 31 / 05$ & No & 1.02 & 3,264 \\
\hline Lithuania & 71 & $12 / 31 / 05$ & Yes (2007 Q4) & 1.10 & 0 \\
\hline Luxembourg & 11 & $12 / 31 / 05$ & Yes (2009 Q4) & 1.94 & 0 \\
\hline Netherlands & 3,443 & $12 / 31 / 05$ & Yes (2005 Q4) & 1.76 & 194 \\
\hline Norway & 4,897 & $12 / 31 / 05$ & Yes (2005 Q4) & 1.39 & 94 \\
\hline Poland & 5,454 & $12 / 31 / 05$ & No & 0.61 & 205 \\
\hline Portugal & 1,361 & $12 / 31 / 05$ & No & 1.21 & 121 \\
\hline Slovakia & 63 & $12 / 31 / 05$ & No & 0.95 & 0 \\
\hline Slovenia & 208 & $12 / 31 / 05$ & No & 0.88 & 0 \\
\hline Spain & 3,195 & $12 / 31 / 05$ & No & 1.29 & 0 \\
\hline Sweden & 8,071 & $12 / 31 / 05$ & Yes (2007 Q3) & 1.69 & 181 \\
\hline United Kingdom & 18,809 & $12 / 31 / 05$ & Yes (2005 Q2) & 1.68 & 217 \\
\hline \multicolumn{6}{|c|}{ IFRS Adoption Countries Outside the European Union (IFRS $\left.S_{\text {non-EU }}\right)$ : } \\
\hline Abu Dhabi & 308 & $12 / 31 / 03$ & No & 0.82 & 0 \\
\hline Australia & 31,543 & $12 / 31 / 05$ & No & 1.60 & 523 \\
\hline Hong Kong & 23,222 & $12 / 31 / 05$ & Yes (2008 Q3) & 1.76 & 460 \\
\hline Israel & 385 & $12 / 31 / 08$ & n.a. & 0.91 & 8 \\
\hline New Zealand & 3,060 & $12 / 31 / 07$ & No & 1.71 & 0 \\
\hline Pakistan & 722 & $12 / 31 / 07$ & No & -0.73 & 61 \\
\hline Philippines & 4,495 & $12 / 31 / 05$ & n.a. & -0.06 & 36 \\
\hline Singapore & 14,841 & $12 / 31 / 03$ & No & 1.84 & 789 \\
\hline South Africa & 6,635 & $12 / 31 / 05$ & No & 0.58 & 277 \\
\hline Switzerland & 5,927 & $12 / 31 / 05$ & No & 1.63 & 3,578 \\
\hline Turkey & 5,842 & $12 / 31 / 06$ & Yes (2008 Q1) & 0.08 & 2,019 \\
\hline \multicolumn{6}{|c|}{ Non-IFRS Countries (Benchmark Sample): } \\
\hline Argentina & 128 & n.a. & No & -0.71 & 0 \\
\hline Brazil & 4,585 & n.a. & No & 0.31 & 0 \\
\hline Canada & 13,226 & n.a. & No & 1.52 & 22 \\
\hline Channel Islands & 436 & n.a. & n.a. & n.a. & 0 \\
\hline Chile & 280 & n.a. & Yes (2009 Q2) & 1.48 & 0 \\
\hline China & 39,562 & n.a. & No & -0.39 & 649 \\
\hline Egypt & 1,635 & n.a. & No & -0.51 & 108 \\
\hline India & 156 & n.a. & No & -0.33 & 0 \\
\hline Indonesia & 6,864 & n.a. & No & -0.65 & 0 \\
\hline Japan & 108,877 & n.a. & Yes (2005 Q3) & 0.99 & 35 \\
\hline South Korea & 28,630 & n.a. & n.a. & 0.67 & 0 \\
\hline Malaysia & 26,509 & n.a. & n.a. & 0.66 & 0 \\
\hline Mexico & 912 & n.a. & No & 0.37 & 0 \\
\hline Morocco & 397 & n.a. & n.a. & -0.18 & 0 \\
\hline Qatar & 179 & n.a. & n.a. & 0.28 & 0 \\
\hline Russian Federation & 1,114 & n.a. & No & -0.37 & 240 \\
\hline Saudi Arabia & 918 & n.a. & n.a. & -0.01 & 0 \\
\hline Sri Lanka & 249 & n.a. & No & 0.13 & 0 \\
\hline Taiwan & 15,305 & n.a. & No & 0.94 & 0 \\
\hline Thailand & 11,526 & n.a. & No & 0.24 & 30 \\
\hline United States & 163,016 & n.a. & n.a. & 1.48 & 0 \\
\hline
\end{tabular}




\begin{tabular}{|c|c|c|c|c|c|c|c|c|c|c|c|c|c|}
\hline \multirow[b]{2}{*}{ Country } & \multicolumn{2}{|c|}{$\begin{array}{c}\text { IFRS \& Substantive } \Delta \\
\text { Enforcement in EU } \\
\text { (Table 3) } \\
\end{array}$} & \multicolumn{6}{|c|}{$\begin{array}{c}\text { IFRS Conditional on Regulatory } \\
\text { Quality and } \Delta \text { Enforcement } \\
\text { (Table 4) }\end{array}$} & \multicolumn{5}{|c|}{$\begin{array}{c}\text { Separating Liquidity Effects of } \\
\text { IFRS and } \Delta \text { Enforcement } \\
\text { (Table 6) }\end{array}$} \\
\hline & 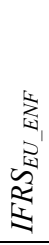 & 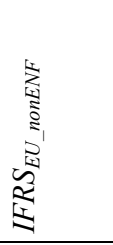 & 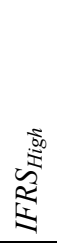 & 离 & 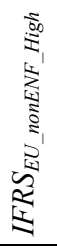 & 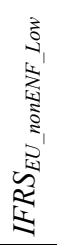 & 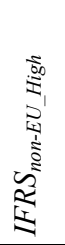 & 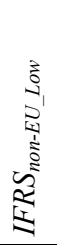 & 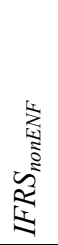 & 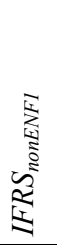 & 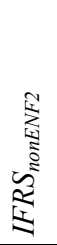 & $\sum_{\substack{i=1 \\
y}}^{\substack{1 \\
y}}$ & 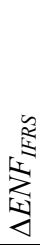 \\
\hline \multicolumn{14}{|c|}{ European Union Countries (IFRS $\left.S_{E U}\right)$ : } \\
\hline Austria & 0 & 1 & 1 & 0 & 1 & 0 & 0 & 0 & 1 & 0 & 1 & 0 & 0 \\
\hline Belgium & 0 & 1 & 1 & 0 & 1 & 0 & 0 & 0 & 1 & 0 & 1 & 0 & 0 \\
\hline Czech Republic & 0 & 1 & 0 & 1 & 0 & 1 & 0 & 0 & 1 & 0 & 1 & 0 & 0 \\
\hline Denmark & 0 & 1 & 1 & 0 & 1 & 0 & 0 & 0 & 1 & 0 & 1 & 0 & 0 \\
\hline Estonia & 0 & 1 & 1 & 0 & 1 & 0 & 0 & 0 & 1 & 1 & 0 & 1 & 1 \\
\hline Finland & 1 & 0 & 1 & 0 & 0 & 0 & 0 & 0 & 0 & 0 & 0 & 0 & 0 \\
\hline France & 0 & 1 & 0 & 1 & 0 & 1 & 0 & 0 & 1 & 0 & 1 & 0 & 0 \\
\hline Germany & 1 & 0 & 1 & 0 & 0 & 0 & 0 & 0 & 0 & 0 & 0 & 0 & 0 \\
\hline Greece & 0 & 1 & 0 & 1 & 0 & 1 & 0 & 0 & 1 & 0 & 1 & 0 & 0 \\
\hline Hungary & 0 & 1 & 0 & 1 & 0 & 1 & 0 & 0 & 1 & 1 & 0 & 1 & 1 \\
\hline Iceland & 1 & 0 & 1 & 0 & 0 & 0 & 0 & 0 & 0 & 0 & 0 & 0 & 0 \\
\hline Ireland & 0 & 1 & 1 & 0 & 1 & 0 & 0 & 0 & 1 & 1 & 0 & 1 & 1 \\
\hline Italy & 0 & 1 & 0 & 1 & 0 & 1 & 0 & 0 & 1 & 0 & 1 & 0 & 0 \\
\hline Lithuania & 0 & 1 & 0 & 1 & 0 & 1 & 0 & 0 & 1 & 1 & 0 & 1 & 1 \\
\hline Luxembourg & 0 & 1 & 1 & 0 & 1 & 0 & 0 & 0 & 1 & 1 & 0 & 1 & 1 \\
\hline Netherlands & 1 & 0 & 1 & 0 & 0 & 0 & 0 & 0 & 0 & 0 & 0 & 0 & 0 \\
\hline Norway & 1 & 0 & 1 & 0 & 0 & 0 & 0 & 0 & 0 & 0 & 0 & 0 & 0 \\
\hline Poland & 0 & 1 & 0 & 1 & 0 & 1 & 0 & 0 & 1 & 0 & 1 & 0 & 0 \\
\hline Portugal & 0 & 1 & 0 & 1 & 0 & 1 & 0 & 0 & 1 & 0 & 1 & 0 & 0 \\
\hline Slovakia & 0 & 1 & 0 & 1 & 0 & 1 & 0 & 0 & 1 & 0 & 1 & 0 & 0 \\
\hline Slovenia & 0 & 1 & 0 & 1 & 0 & 1 & 0 & 0 & 1 & 0 & 1 & 0 & 0 \\
\hline Spain & 0 & 1 & 1 & 0 & 1 & 0 & 0 & 0 & 1 & 0 & 1 & 0 & 0 \\
\hline Sweden & 0 & 1 & 1 & 0 & 1 & 0 & 0 & 0 & 1 & 1 & 0 & 1 & 1 \\
\hline United Kingdom & 1 & 0 & 1 & 0 & 0 & 0 & 0 & 0 & 0 & 0 & 0 & 0 & 0 \\
\hline \multicolumn{14}{|c|}{ IFRS Adoption Countries Outside the European Union (IFRS $\left.S_{\text {non-EU }}\right)$ : } \\
\hline Abu Dhabi & 0 & 0 & 0 & 1 & 0 & 0 & 0 & 1 & 1 & 0 & 1 & 0 & 0 \\
\hline Australia & 0 & 0 & 1 & 0 & 0 & 0 & 1 & 0 & 1 & 0 & 1 & 0 & 0 \\
\hline Hong Kong & 0 & 0 & 1 & 0 & 0 & 0 & 1 & 0 & 1 & 1 & 0 & 0 & 1 \\
\hline Israel & 0 & 0 & 0 & 1 & 0 & 0 & 0 & 1 & 1 & 0 & 1 & 0 & 0 \\
\hline New Zealand & 0 & 0 & 1 & 0 & 0 & 0 & 1 & 0 & 1 & 0 & 1 & 0 & 0 \\
\hline Pakistan & 0 & 0 & 0 & 1 & 0 & 0 & 0 & 1 & 1 & 0 & 1 & 0 & 0 \\
\hline Philippines & 0 & 0 & 0 & 1 & 0 & 0 & 0 & 1 & 1 & 0 & 1 & 0 & 0 \\
\hline Singapore & 0 & 0 & 1 & 0 & 0 & 0 & 1 & 0 & 1 & 0 & 1 & 0 & 0 \\
\hline South Africa & 0 & 0 & 0 & 1 & 0 & 0 & 0 & 1 & 1 & 0 & 1 & 0 & 0 \\
\hline Switzerland & 0 & 0 & 1 & 0 & 0 & 0 & 1 & 0 & 1 & 0 & 1 & 0 & 0 \\
\hline Turkey & 0 & 0 & 0 & 1 & 0 & 0 & 0 & 1 & 1 & 1 & 0 & 0 & 1 \\
\hline
\end{tabular}

The treatment sample consists of all countries in and outside the European Union (EU), which mandated IFRS reporting before 2009. We also include Iceland and Norway from the European Economic Area (EEA) in the EU sample, as they agreed to adopt the EU capital market directives in their entirety. The sample comprises all firmquarter observations over the 2001 to 2009 period with liquidity and control variable data available in Datastream and accounting standards information in Worldscope. We exclude firms reporting under U.S. GAAP, cross-listed in the U.S., with market values of equity below US\$ 5 million, and trading on an unregulated EU market. In Panel A, we present (i) the number of firm-quarter observations used in the analysis (based on the bid-ask spread sample), (ii) the dates when IFRS reporting became mandatory (Daske et al. 2008), (iii) whether and when a substantive change $(\Delta)$ in enforcement occurred over the sample period (based on a survey of national regulators and audit firms and publicly available sources; n.a. indicates no reply), (iv) the Regulatory Quality index taken from Kaufman et al. (2009) and measured as of 2003, and (v) the number of firm-quarter observations of firms that voluntarily adopted IFRS before the mandate (used in Table 5). In Panel B, we present the coding (treatment sample only) of the main binary indicator variables we use to analyze the liquidity effects of IFRS adoption and substantive changes in enforcement. These country-level variables help us create non-overlapping subsets of IFRS and $\triangle E N F$ (see also Figures 1 and 3). For details on the variable definitions see the respective table notes (as indicated in the heading). 
Table 2: Descriptive Statistics for Variables Used in the Liquidity Regressions

Panel A: Distributional Characteristics

\begin{tabular}{lcccccccc}
\hline \hline & $N$ & Mean & Std. Dev. & $P 1$ & $P 25$ & Median & P75 & P99 \\
\hline Dependent Variables: & & & & & & & & \\
Bid-Ask Spread $_{t}$ & 613,752 & 0.026 & 0.046 & 0.001 & 0.004 & 0.010 & 0.027 & 0.246 \\
Zero Returns $_{t}$ & 762,094 & 0.223 & 0.245 & 0.000 & 0.034 & 0.123 & 0.333 & 0.934 \\
Price Impact $_{t}$ & 719,711 & 2.739 & 8.767 & 0.000 & 0.013 & 0.120 & 1.092 & 49.521 \\
Total Trading Costs $_{t}$ & 699,517 & 0.043 & 0.045 & 0.010 & 0.013 & 0.026 & 0.051 & 0.219 \\
Liquidity Factor $_{t}$ & 561,590 & -0.089 & 0.858 & -0.745 & -0.630 & -0.410 & 0.081 & 3.355 \\
& & & & & & & & \\
Independent Variables: & & & & & & & & \\
Market Value $_{t-4}$ & 613,752 & 1,158 & 7,701 & 3 & 36 & 126 & 478 & 17,207 \\
Share Turnover $_{t-4}$ & 613,752 & 0.003 & 0.004 & 0.000 & 0.000 & 0.001 & 0.004 & 0.022 \\
Return Variability $_{t-4}$ & 613,752 & 0.027 & 0.013 & 0.007 & 0.017 & 0.025 & 0.035 & 0.066 \\
\hline \hline
\end{tabular}

Panel B: Pearson's Correlation Coefficients

\begin{tabular}{|c|c|c|c|c|c|c|c|}
\hline & $\begin{array}{c}\text { Zero } \\
\text { Returns }\end{array}$ & $\begin{array}{l}\text { Price } \\
\text { Impact }\end{array}$ & $\begin{array}{c}\text { Total } \\
\text { Trading } \\
\text { Costs }\end{array}$ & $\begin{array}{l}\text { Liquidity } \\
\text { Factor }\end{array}$ & $\begin{array}{c}\text { Market } \\
\text { Value }\end{array}$ & $\begin{array}{c}\text { Share } \\
\text { Turnover }\end{array}$ & $\begin{array}{c}\text { Return } \\
\text { Variability }\end{array}$ \\
\hline Bid-Ask Spread $_{t}$ & 0.670 & 0.692 & 0.804 & 0.901 & -0.071 & -0.241 & 0.195 \\
\hline Zero Returns $_{t}$ & & 0.472 & 0.730 & 0.791 & -0.108 & -0.337 & 0.022 \\
\hline Price Impact $_{t}$ & & & 0.646 & 0.733 & -0.065 & -0.151 & 0.196 \\
\hline Total Trading Costs ${ }_{t}$ & & & & 0.972 & -0.092 & -0.210 & 0.307 \\
\hline Liquidity Factor $_{t}$ & & & & & -0.134 & -0.253 & 0.263 \\
\hline Market Value $_{t-4}$ & & & & & & 0.059 & -0.071 \\
\hline Share Turnover $r_{t-4}$ & & & & & & & 0.226 \\
\hline
\end{tabular}

The sample consists of all firm-quarter observations with liquidity and control variable data available in Datastream and accounting standards information in Worldscope from up to 35 IFRS treatment countries and 21 benchmark countries over the 2001 to 2009 period. The table presents distributional characteristics (Panel A) and Pearson's correlation coefficients (Panel B) of the dependent variables and the firm-level independent variables used in the analyses. The five dependent variables are: (1) The Bid-Ask Spread is the quarterly median quoted spread (i.e., difference between the bid and ask price divided by the mid-point and measured at the end of each trading day). (2) Zero Returns is the proportion of trading days with zero daily stock returns out of all potential trading days in a given quarter. (3) Price Impact is the quarterly median of the Amihud (2002) illiquidity measure (i.e., daily absolute stock return divided by US\$ trading volume). (4) Total Trading Costs is a quarterly estimate of total round-trip transaction costs (i.e., bid-ask spreads, commissions as well as implicit costs such as short-sale constraints or taxes) inferred from the time-series of daily security and aggregate market returns, as developed by Lesmond, Ogden, and Trzcinka (1999). (5) The Liquidity Factor is an aggregate liquidity measure and represents the scores of a single factor extracted from the above four liquidity variables employing factor analysis. The continuous independent variables consist of the following measures: Market Value is stock price times the number of shares outstanding (in US\$ million) measured at the end of the quarter. Share Turnover is the quarterly median of the daily turnover (i.e., US\$ trading volume divided by the market value at the end of each trading day). We compute Return Variability as the standard deviation of daily stock returns in a given quarter. We report the independent variables for the bid-ask spread sample. All correlation coefficients are significant at the $1 \%$ level. All variables are truncated at the $1^{\text {st }}$ and $99^{\text {th }}$ percentile. The subscript $t$ indicates the calendar quarter of variable measurement. 
Table 3: Liquidity Effects of IFRS Adoption Globally, in the EU, and in EU Countries with Bundled Substantive Enforcement Changes Panel A: Ln(Bid-Ask Spread) as the Dependent Variable

\begin{tabular}{|c|c|c|c|c|c|c|c|}
\hline & \multirow{2}{*}{$\begin{array}{c}\text { Global IFRS } \\
\text { Two Quarter- } \\
\text { Year Trends } \\
\text { (1) }\end{array}$} & \multicolumn{4}{|c|}{ EU vs. Non-EU IFRS } & \multicolumn{2}{|c|}{$\begin{array}{c}\text { IFRS in EU with vs. without } \\
\text { Bundled } \Delta \text { Enforcement }\end{array}$} \\
\hline & & $\begin{array}{l}\text { Three Quarter- } \\
\text { Year Trends } \\
\text { (2) }\end{array}$ & $\begin{array}{c}\text { Other FSAP } \\
\text { Directives } \\
\text { (3) }\end{array}$ & $\begin{array}{c}\text { Within Country } \\
\text { Estimation } \\
\text { (4) }\end{array}$ & $\begin{array}{c}\text { Treatment } \\
\text { Countries Only } \\
\text { (5) }\end{array}$ & $\begin{array}{l}\text { Three Quarter- } \\
\text { Year Trends } \\
\text { (6) }\end{array}$ & $\begin{array}{c}\text { Within Country } \\
\text { Estimation } \\
(7)\end{array}$ \\
\hline \multicolumn{8}{|l|}{ IFRS Variables: } \\
\hline IFRS & $\begin{array}{c}-0.008 \\
(-0.11)\end{array}$ & - & - & - & - & - & - \\
\hline $\mathrm{IFRS}_{\mathrm{EU}}$ & - & $\begin{array}{l}-0.178^{* *} \\
(-2.51)\end{array}$ & $\begin{array}{l}-0.169 * * \\
(-2.43)\end{array}$ & $\begin{array}{l}-0.117 * * \\
(-2.00)\end{array}$ & $\begin{array}{l}-0.200 * * * \\
(-3.26)\end{array}$ & - & - \\
\hline IFRS $_{\text {EU_ENF }}$ & - & - & - & - & - & $\begin{array}{l}-0.431 * * * \\
(-3.15)\end{array}$ & $\begin{array}{l}-0.192 * * * \\
(-4.18)\end{array}$ \\
\hline IFRS $_{\text {EU_nonENF }}$ & - & - & - & - & - & $\begin{array}{r}-0.007 \\
(-0.08)\end{array}$ & $\begin{array}{c}-0.071 \\
(-0.92)\end{array}$ \\
\hline IFRS $_{\text {non-EU }}$ & - & $\begin{array}{c}0.088 \\
(1.15)\end{array}$ & $\begin{array}{c}0.088 \\
(1.15)\end{array}$ & $\begin{array}{r}0.057 \\
(0.68)\end{array}$ & $\begin{array}{r}0.088 \\
(1.11)\end{array}$ & $\begin{array}{c}0.088 \\
(1.15)\end{array}$ & $\begin{array}{r}0.057 \\
(0.68)\end{array}$ \\
\hline F-test for Differences [p-value]: & & {$[0.01]$} & {$[0.02]$} & {$[0.09]$} & {$[0.01]$} & {$[0.02]$} & {$[0.11]$} \\
\hline \multicolumn{8}{|l|}{ Firm-level Control Variables: } \\
\hline Ln(Market Value $\left.{ }_{t-4}\right)$ & $\begin{array}{l}-0.385 * * * \\
(-26.05)\end{array}$ & $\begin{array}{l}-0.385^{* * * *} \\
(-26.10)\end{array}$ & $\begin{array}{l}-0.385^{* * * *} \\
(-26.13)\end{array}$ & $\begin{array}{l}-0.387 * * * \\
(-29.17)\end{array}$ & $\begin{array}{l}-0.388 * * * \\
(-24.28)\end{array}$ & $\begin{array}{l}-0.385^{* * *} \\
(-26.16)\end{array}$ & $\begin{array}{l}-0.387 * * * \\
(-29.17)\end{array}$ \\
\hline Ln(Share Turnover $\left.{ }_{t-4}\right)$ & $\begin{array}{l}-0.306 * * * \\
(-9.12)\end{array}$ & $\begin{array}{l}-0.306^{* * *} \\
(-9.10)\end{array}$ & $\begin{array}{l}-0.307 * * * \\
(-9.11)\end{array}$ & $\begin{array}{l}-0.307 * * * \\
(-9.05)\end{array}$ & $\begin{array}{l}-0.253 * * * \\
(-16.90)\end{array}$ & $\begin{array}{l}-0.307 * * * \\
(-9.16)\end{array}$ & $\begin{array}{l}-0.307 * * * \\
(-9.05)\end{array}$ \\
\hline $\operatorname{Ln}\left(\right.$ Return Variability $\left._{t-4}\right)$ & $\begin{array}{l}0.386^{* * *} \\
(6.77)\end{array}$ & $\begin{array}{l}0.383 * * * \\
(6.59)\end{array}$ & $\begin{array}{l}0.383 * * * \\
(6.59)\end{array}$ & $\begin{array}{l}0.384 * * * \\
(6.76)\end{array}$ & $\begin{array}{l}0.280 * * * \\
(7.09)\end{array}$ & $\begin{array}{l}0.386 * * * \\
(6.71)\end{array}$ & $\begin{array}{l}0.384 * * * \\
(6.77)\end{array}$ \\
\hline \multicolumn{8}{|l|}{ Other FSAP Directives: } \\
\hline MAD & - & - & $\begin{array}{l}-0.231 * * * \\
(-4.11)\end{array}$ & - & - & - & - \\
\hline TPD & - & - & $\begin{array}{l}-0.308 * * \\
(-2.27)\end{array}$ & - & - & - & - \\
\hline Takeover & - & - & $\begin{array}{c}0.121 \\
(1.60)\end{array}$ & - & - & - & - \\
\hline MiFID & - & - & $\begin{array}{r}0.021 \\
(0.12)\end{array}$ & - & - & - & - \\
\hline PROSP & - & - & $\begin{array}{c}0.101 \\
(1.39)\end{array}$ & - & - & - & - \\
\hline Country \& Industry Fixed Effects & Yes & Yes & Yes & Yes & Yes & Yes & Yes \\
\hline Quarter-Year Fixed Effects & $\begin{array}{l}\text { Global \& } \\
\text { IFRS } \\
\text { Countries }\end{array}$ & $\begin{array}{l}\text { Global, } \\
\text { IFRS \& EU } \\
\text { Countries }\end{array}$ & $\begin{array}{l}\text { Global, } \\
\text { IFRS \& EU } \\
\text { Countries }\end{array}$ & $\begin{array}{l}\text { For Each } \\
\text { Country } \\
\text { Separately }\end{array}$ & $\begin{array}{l}\text { IFRS \& EU } \\
\text { Countries }\end{array}$ & $\begin{array}{l}\text { Global, } \\
\text { IFRS \& EU } \\
\text { Countries }\end{array}$ & $\begin{array}{l}\text { For Each } \\
\text { Country } \\
\text { Separately }\end{array}$ \\
\hline R-squared & 0.767 & 0.768 & 0.769 & 0.795 & 0.716 & 0.769 & 0.795 \\
\hline Observations & 613,752 & 613,752 & 613,752 & 613,752 & 189,248 & 613,752 & 613,752 \\
\hline
\end{tabular}




\begin{tabular}{|c|c|c|c|c|c|c|c|}
\hline & \multirow{2}{*}{$\begin{array}{c}\text { Global IFRS } \\
\text { Two Quarter- } \\
\text { Year Trends } \\
\text { (1) }\end{array}$} & \multicolumn{4}{|c|}{ EU vs. Non-EU IFRS } & \multicolumn{2}{|c|}{$\begin{array}{l}\text { IFRS in EU with vs. without } \\
\text { Bundled } \Delta \text { Enforcement }\end{array}$} \\
\hline & & $\begin{array}{l}\text { Three Quarter- } \\
\text { Year Trends } \\
\text { (2) }\end{array}$ & $\begin{array}{c}\text { Other FSAP } \\
\text { Directives } \\
(3)\end{array}$ & $\begin{array}{c}\text { Within Country } \\
\text { Estimation } \\
(4) \\
\end{array}$ & $\begin{array}{c}\text { Treatment } \\
\text { Countries Only } \\
(5)\end{array}$ & $\begin{array}{c}\text { Three Quarter- } \\
\text { Year Trends } \\
\text { (6) }\end{array}$ & $\begin{array}{c}\text { Within Country } \\
\text { Estimation } \\
(7) \\
\end{array}$ \\
\hline \multicolumn{8}{|l|}{ IFRS Variables: } \\
\hline IFRS & $\begin{array}{l}-0.035 \\
(-0.86)\end{array}$ & - & - & - & - & - & - \\
\hline IFRS $_{\mathrm{EU}}$ & - & $\begin{array}{l}-0.124 * * * \\
(-3.07)\end{array}$ & $\begin{array}{l}-0.123 * * * \\
(-3.00)\end{array}$ & $\begin{array}{l}-0.117 * * * \\
(-2.91)\end{array}$ & $\begin{array}{l}-0.096^{* *} \\
(-2.43)\end{array}$ & - & - \\
\hline $\mathrm{IFRS}_{\mathrm{EU} \_\mathrm{ENF}}$ & - & - & - & - & - & $\begin{array}{l}-0.259 * * * \\
(-4.63)\end{array}$ & $\begin{array}{l}-0.195 * * * \\
(-5.18)\end{array}$ \\
\hline IFRS $_{\text {EU_nonENF }}$ & - & - & - & - & - & $\begin{array}{c}-0.040 \\
(-0.66)\end{array}$ & $\begin{array}{r}-0.077 \\
(-1.47)\end{array}$ \\
\hline IFRS $_{\text {non-EU }}$ & - & $\begin{array}{c}0.018 \\
(0.47)\end{array}$ & $\begin{array}{r}0.018 \\
(0.47)\end{array}$ & $\begin{array}{r}0.028 \\
(0.75)\end{array}$ & $\begin{array}{r}0.023 \\
(0.61)\end{array}$ & $\begin{array}{c}0.018 \\
(0.47)\end{array}$ & $\begin{array}{c}0.028 \\
(0.75)\end{array}$ \\
\hline F-test for Differences [p-value]: & & {$[0.01]$} & {$[0.01]$} & {$[0.01]$} & {$[0.02]$} & {$[0.01]$} & {$[0.04]$} \\
\hline \multicolumn{8}{|l|}{ Firm-level Control Variables: } \\
\hline Ln(Market Value $\left.{ }_{t-4}\right)$ & $\begin{array}{l}-0.216^{* * *} \\
(-21.26)\end{array}$ & $\begin{array}{l}-0.216^{* * *} \\
(-21.05)\end{array}$ & $\begin{array}{l}-0.216^{* * *} \\
(-21.05)\end{array}$ & $\begin{array}{l}-0.216^{* * *} \\
(-19.84)\end{array}$ & $\begin{array}{l}-0.243 * * * \\
(-16.12)\end{array}$ & $\begin{array}{l}-0.216^{* * *} \\
(-21.07)\end{array}$ & $\begin{array}{l}-0.216^{* * *} \\
(-19.84)\end{array}$ \\
\hline Ln(Share Turnover $\left.{ }_{t-4}\right)$ & $\begin{array}{l}-0.146^{* * * *} \\
(-16.51)\end{array}$ & $\begin{array}{l}-0.146^{* * * *} \\
(-16.42)\end{array}$ & $\begin{array}{l}-0.146 * * * \\
(-16.46)\end{array}$ & $\begin{array}{l}-0.150 * * * \\
(-18.53)\end{array}$ & $\begin{array}{l}-0.140 * * * \\
(-18.15)\end{array}$ & $\begin{array}{l}-0.147 * * * \\
(-16.54)\end{array}$ & $\begin{array}{l}-0.150 * * * \\
(-18.54)\end{array}$ \\
\hline Ln(Return Variability $\left.{ }_{t-4}\right)$ & $\begin{array}{l}0.259 * * * \\
(11.42)\end{array}$ & $\begin{array}{l}0.258 * * * \\
(11.46)\end{array}$ & $\begin{array}{l}0.258 * * * \\
(11.49)\end{array}$ & $\begin{array}{l}0.255^{* * * *} \\
(10.63)\end{array}$ & $\begin{array}{l}0.240 * * * \\
(5.97)\end{array}$ & $\begin{array}{l}0.259 * * * \\
(11.67)\end{array}$ & $\begin{array}{l}0.255^{* * *} \\
(10.63)\end{array}$ \\
\hline \multicolumn{8}{|l|}{ Other FSAP Directives: } \\
\hline MAD & - & - & $\begin{array}{l}-0.127 * * * \\
(-6.45)\end{array}$ & - & - & - & - \\
\hline TPD & - & - & $\begin{array}{l}-0.112 * * \\
(-2.34)\end{array}$ & - & - & - & - \\
\hline Takeover & - & - & $\begin{array}{l}-0.017 \\
(-0.90)\end{array}$ & - & - & - & - \\
\hline MiFID & - & - & $\begin{array}{c}0.020 \\
(0.53)\end{array}$ & - & - & - & - \\
\hline PROSP & - & - & $\begin{array}{l}-0.024 \\
(-1.21)\end{array}$ & - & - & - & - \\
\hline Country \& Industry Fixed Effects & Yes & Yes & Yes & Yes & Yes & Yes & Yes \\
\hline Quarter-Year Fixed Effects & $\begin{array}{l}\text { Global \& } \\
\text { IFRS } \\
\text { Countries } \\
\end{array}$ & $\begin{array}{l}\text { Global, } \\
\text { IFRS \& EU } \\
\text { Countries } \\
\end{array}$ & $\begin{array}{l}\text { Global, } \\
\text { IFRS \& EU } \\
\text { Countries }\end{array}$ & $\begin{array}{l}\text { For Each } \\
\text { Country } \\
\text { Separately }\end{array}$ & $\begin{array}{l}\text { IFRS \& EU } \\
\text { Countries }\end{array}$ & $\begin{array}{l}\text { Global, } \\
\text { IFRS \& EU } \\
\text { Countries }\end{array}$ & $\begin{array}{l}\text { For Each } \\
\text { Country } \\
\text { Separately }\end{array}$ \\
\hline R-squared & 0.652 & 0.653 & 0.653 & 0.677 & 0.676 & 0.654 & 0.677 \\
\hline Observations & 561,590 & 561,590 & 561,590 & 561,590 & 168,793 & 561,590 & 561,590 \\
\hline
\end{tabular}




\section{Table 3 (continued)}

The sample comprises firm-quarter observations from up to 35 (21) IFRS treatment (benchmark) countries over the 2001 to 2009 period. We report results for two dependent variables: (1) the Bid-Ask Spread measured as the quarterly median quoted spread (Panel A), and (2) the Liquidity Factor equal to the factor scores extracted from the four individual measures bid-ask spreads, zero returns, price impact, and total trading costs using factor analysis (Panel B). IFRS is a binary indicator variable for firm-quarters with IFRS reporting that takes on the value of ' 1 ' beginning in the calendar quarter following the first fiscal-year end after IFRS became mandatory. We identify firms that do not follow IFRS after the mandate based on the "accounting standards followed" field in Worldscope (field 07536). For the analyses in this table we partition the IFRS observations into non-overlapping subsets using binary indicator variables: (i) We distinguish between firms from EU countries $\left(I F R S_{E U}\right)$ and firms from outside the EU (IFRS non-EU). (ii) We further distinguish between firms from EU countries that bundled IFRS adoption with substantive changes $(\triangle)$ in enforcement $\left(I F R S_{E U E N F}\right)$, and firms from EU countries with no such bundling $\left(I F R S_{E U n n o n E N F}\right)$. For a description of the firm-level controls see Table 2. In Model 3 we also include binary indicator variables for other regulatory changes in the EU, i.e., the Market Abuse Directive (MAD), the Transparency Directive (TPD), the Takeover Directive (Takeover), the Markets in Financial Instruments Directive (MiFID), and the Prospectus Directive (PROSP). See Christensen et al. (2013) for details. We include country-, Campbell (1996) industry-, and quarter-year-fixed effects (globally, for IFRS countries, EU countries, or each country separately, as indicated in the table) in the regressions, but do not report the coefficients. If indicated, we use the natural $\log$ of the raw values (plus one), and lag the variables by four quarters. The table reports OLS coefficient estimates and (in parentheses) t-statistics based on robust standard errors that are clustered by country and calendar quarter. We also report p-values from Wald tests assessing the statistical significance of the differences across the IFRS coefficients (the IFRS $S_{E U E N F}$ and IFRS $S_{E U_{-} n \text { noNF }}$ coefficients in the last two columns). ***, **, and * indicate statistical significance at the $1 \%, 5 \%$, and $10 \%$ levels (two-tailed). 


\begin{tabular}{|c|c|c|c|c|c|c|}
\hline & \multicolumn{3}{|c|}{ Ln(Bid-Ask Spread) } & \multicolumn{3}{|c|}{ Ln(Liquidity Factor +1$)$} \\
\hline & \multicolumn{3}{|c|}{ High vs. Low Regulatory Quality } & \multicolumn{3}{|c|}{ High vs. Low Regulatory Quality } \\
\hline & \multirow[b]{2}{*}{$\begin{array}{c}\text { Three Quarter- } \\
\text { Year Trends } \\
\text { (1) }\end{array}$} & \multicolumn{2}{|c|}{$\begin{array}{c}\text { With or without Bundled } \\
\Delta \text { Enforcement in EU }\end{array}$} & \multirow[b]{2}{*}{$\begin{array}{l}\text { Three Quarter- } \\
\text { Year Trends } \\
\text { (1) }\end{array}$} & \multicolumn{2}{|c|}{$\begin{array}{c}\text { With or without Bundled } \\
\Delta \text { Enforcement in EU }\end{array}$} \\
\hline & & $\begin{array}{c}\text { Three Quarter- } \\
\text { Year Trends } \\
\text { (2) }\end{array}$ & $\begin{array}{c}\text { Within Country } \\
\text { Estimation } \\
\text { (3) }\end{array}$ & & $\begin{array}{l}\text { Three Quarter- } \\
\text { Year Trends } \\
\text { (2) }\end{array}$ & $\begin{array}{c}\text { Within Country } \\
\text { Estimation } \\
\text { (3) }\end{array}$ \\
\hline \multicolumn{7}{|l|}{ Global IFRS: } \\
\hline IFRS $_{\text {High }}$ & $\begin{array}{l}-0.064 \\
(-0.64)\end{array}$ & - & - & $\begin{array}{l}-0.063 \\
(-1.22)\end{array}$ & - & - \\
\hline IFRS $_{\text {Low }}$ & $\begin{array}{r}0.115 \\
(1.17)\end{array}$ & - & - & $\begin{array}{c}0.038 \\
(0.78)\end{array}$ & - & - \\
\hline \multicolumn{7}{|l|}{ IFRS in EU: } \\
\hline $\mathrm{IFRS}_{\mathrm{EU} \_\mathrm{ENF}}$ & - & $\begin{array}{l}-0.432 * * * \\
(-3.17)\end{array}$ & $\begin{array}{l}-0.192 * * * \\
(-4.18)\end{array}$ & - & $\begin{array}{l}-0.260 * * * \\
(-4.69)\end{array}$ & $\begin{array}{l}-0.195 * * * \\
(-5.18)\end{array}$ \\
\hline $\mathrm{IFRS}_{\mathrm{EU} \_ \text {nonENF_High }}$ & - & $\begin{array}{l}-0.065 \\
(-0.80)\end{array}$ & $\begin{array}{l}-0.071 \\
(-1.21)\end{array}$ & - & $\begin{array}{l}-0.064 \\
(-1.10)\end{array}$ & $\begin{array}{l}-0.111 * * * \\
(-6.54)\end{array}$ \\
\hline $\mathrm{IFRS}_{\mathrm{EU} \_ \text {nonENF_Low }}$ & - & $\begin{array}{c}0.030 \\
(0.24)\end{array}$ & $\begin{array}{l}-0.071 \\
(-0.63)\end{array}$ & - & $\begin{array}{l}-0.024 \\
(-0.37)\end{array}$ & $\begin{array}{l}-0.056 \\
(-0.69)\end{array}$ \\
\hline \multicolumn{7}{|l|}{ IFRS outside EU: } \\
\hline IFRS $_{\text {non-EU_High }}$ & - & $\begin{array}{c}0.096 \\
(0.94)\end{array}$ & $\begin{array}{l}-0.056 \\
(-1.18)\end{array}$ & - & $\begin{array}{r}0.017 \\
(0.33)\end{array}$ & $\begin{array}{l}-0.021 \\
(-0.88)\end{array}$ \\
\hline IFRS $_{\text {non-EU_Low }}$ & - & $\begin{array}{r}0.055 \\
(0.48)\end{array}$ & $\begin{array}{l}0.210^{* *} \\
(2.49)\end{array}$ & - & $\begin{array}{r}0.021 \\
(0.53)\end{array}$ & $\begin{array}{l}0.095 * * * \\
(3.41)\end{array}$ \\
\hline \multicolumn{7}{|l|}{ F-test for Differences [p-value]: } \\
\hline $\mathrm{IFRS}_{\mathrm{High}}=\mathrm{IFRS}_{\text {Low }}$ & {$[0.21]$} & - & - & {$[0.11]$} & - & - \\
\hline $\mathrm{IFRS}_{\mathrm{EU} \_\mathrm{ENF}}=\mathrm{IFRS}_{\mathrm{EU} \_ \text {nonENF_High }}$ & - & {$[0.04]$} & {$[0.02]$} & - & {$[0.02]$} & {$[0.01]$} \\
\hline $\mathrm{IFRS}_{\mathrm{EU} \_ \text {ENF }}=\mathrm{IFRS}_{\mathrm{EU} \_ \text {nonENF_Low }}$ & - & {$[0.03]$} & {$[0.29]$} & - & {$[0.01]$} & {$[0.10]$} \\
\hline $\mathrm{IFRS}_{\mathrm{EU} \_\mathrm{ENF}}=\mathrm{IFRS}_{\text {non-EU_High }}$ & - & {$[0.00]$} & {$[0.00]$} & - & {$[0.00]$} & {$[0.00]$} \\
\hline Firm-level Control Variables & Yes & Yes & Yes & Yes & Yes & Yes \\
\hline Country \& Industry Fixed Effects & Yes & Yes & Yes & Yes & Yes & Yes \\
\hline Quarter-Year Fixed Effects & $\begin{array}{l}\text { Global, } \\
\text { IFRS \& EU } \\
\text { Countries }\end{array}$ & $\begin{array}{l}\text { Global, } \\
\text { IFRS \& EU } \\
\text { Countries }\end{array}$ & $\begin{array}{l}\text { For Each } \\
\text { Country } \\
\text { Separately }\end{array}$ & $\begin{array}{l}\text { Global, } \\
\text { IFRS \& EU } \\
\text { Countries }\end{array}$ & $\begin{array}{l}\text { Global, } \\
\text { IFRS \& EU } \\
\text { Countries }\end{array}$ & $\begin{array}{l}\text { For Each } \\
\text { Country } \\
\text { Separately }\end{array}$ \\
\hline R-squared & 0.769 & 0.769 & 0.795 & 0.653 & 0.654 & 0.678 \\
\hline Observations & 613,752 & 613,752 & 613,752 & 561,590 & 561,590 & 561,590 \\
\hline
\end{tabular}




\section{Table 4 (continued)}

The sample comprises firm-quarter observations from up to 35 (21) IFRS treatment (benchmark) countries over the 2001 to 2009 period. We report results for Bid-Ask Spreads and the Liquidity Factor as dependent variables. IFRS is a binary indicator variable for firm-quarters with mandatory IFRS reporting. For the analyses in this table we partition the IFRS observations into non-overlapping subsets using binary indicator variables: (i) We distinguish between firms from countries with above $\left(I F R S_{H i g h}\right)$ and below $\left(I F R S_{\text {Low }}\right)$ median values of the Regulatory Quality index taken from Kaufman et al. (2009) and measured as of 2003. (ii) We distinguish between firms from EU countries that bundled IFRS adoption with substantive changes $(\triangle)$ in enforcement $\left(I F R S_{E U E N F}\right)$, and firms

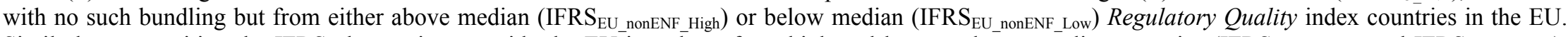
Similarly, we partition the IFRS observations outside the EU into those from high and low regulatory quality countries (IFRS non-EU High $^{-}$and IFRS Throughout the table, we include the full set of firm-level control variables and fixed effects in the models (see Models 2 and 4 in Table 3), but only report OLS coefficient estimates (t-statistics, clustered by country and calendar quarter) for the IFRS variables. We also report p-values from Wald tests assessing the statistical significance of the differences across select IFRS coefficients. ***,**, and * indicate statistical significance at the $1 \%, 5 \%$, and $10 \%$ levels (twotailed). 


\begin{tabular}{|c|c|c|c|c|}
\hline & \multicolumn{2}{|c|}{ Ln(Bid-Ask Spread) } & \multicolumn{2}{|c|}{ Ln(Liquidity Factor +1$)$} \\
\hline & $\begin{array}{c}\text { Three Quarter- } \\
\text { Year Trends } \\
\text { (1) }\end{array}$ & $\begin{array}{c}\text { Within Country } \\
\text { Estimation } \\
(2) \\
\end{array}$ & $\begin{array}{l}\text { Three Quarter- } \\
\text { Year Trends } \\
\text { (1) }\end{array}$ & $\begin{array}{c}\text { Within Country } \\
\text { Estimation } \\
(2)\end{array}$ \\
\hline \multicolumn{5}{|l|}{ Voluntary IFRS (around Mandate) in EU: } \\
\hline vol_IFRS $\mathrm{EU}_{\mathrm{EU}} \mathrm{ENF}$ & $\begin{array}{l}-0.269 * * * \\
(-2.89)\end{array}$ & $\begin{array}{l}-0.303 * * * \\
(-5.46)\end{array}$ & $\begin{array}{l}-0.224 * * * \\
(-3.80)\end{array}$ & $\begin{array}{l}-0.234 * * * \\
(-3.87)\end{array}$ \\
\hline vol_IFRS $\mathrm{EU}_{-}$nonENF & $\begin{array}{c}0.088 \\
(0.76)\end{array}$ & $\begin{array}{l}-0.109 \\
(-1.42)\end{array}$ & $\begin{array}{c}0.058 \\
(0.79)\end{array}$ & $\begin{array}{c}-0.008 \\
(-0.13)\end{array}$ \\
\hline \multicolumn{5}{|l|}{ First-Time Mandatory IFRS in EU: } \\
\hline man_IFRS $\mathrm{EU}_{-} \mathrm{ENF}$ & $\begin{array}{l}-0.443 * * * \\
(-3.23)\end{array}$ & $\begin{array}{l}-0.178 * * * \\
(-3.09)\end{array}$ & $\begin{array}{l}-0.255 * * * \\
(-4.04)\end{array}$ & $\begin{array}{l}-0.182 * * * \\
(-6.94)\end{array}$ \\
\hline man_IFRS $S_{\text {EU_nonENF }}$ & $\begin{array}{l}-0.015 \\
(-0.17)\end{array}$ & $\begin{array}{l}-0.070 \\
(-0.93)\end{array}$ & $\begin{array}{c}-0.049 \\
(-0.83)\end{array}$ & $\begin{array}{l}-0.082 \\
(-1.55)\end{array}$ \\
\hline \multicolumn{5}{|l|}{ IFRS outside EU: } \\
\hline $\mathrm{IFRS}_{\text {non-EU }}$ & $\begin{array}{r}0.088 \\
(1.15)\end{array}$ & $\begin{array}{r}0.057 \\
(0.68)\end{array}$ & $\begin{array}{r}0.018 \\
(0.46)\end{array}$ & $\begin{array}{r}0.027 \\
(0.74)\end{array}$ \\
\hline \multicolumn{5}{|l|}{ F-test for Differences [p-value]: } \\
\hline vol_IFRS $\mathrm{EU}_{\mathrm{EU} E \mathrm{ENF}}=$ vol_IFRS $\mathrm{EU}_{\mathrm{EU} \text { nonENF }}$ & {$[0.00]$} & {$[0.02]$} & {$[0.00]$} & {$[0.01]$} \\
\hline man_IFRS EU_ENF $_{\text {EN }}=$ man_IFRS $S_{\text {EU_nonENF }}$ & {$[0.02]$} & {$[0.20]$} & {$[0.03]$} & {$[0.06]$} \\
\hline Indicator for Voluntary IFRS Adopters in EU & Yes & Yes & Yes & Yes \\
\hline Firm-level Control Variables & Yes & Yes & Yes & Yes \\
\hline Country \& Industry Fixed Effects & Yes & Yes & Yes & Yes \\
\hline Quarter-Year Fixed Effects & $\begin{array}{l}\text { Global, } \\
\text { IFRS \& EU } \\
\text { Countries }\end{array}$ & $\begin{array}{c}\text { For Each } \\
\text { Country } \\
\text { Separately }\end{array}$ & $\begin{array}{l}\text { Global, } \\
\text { IFRS \& EU } \\
\text { Countries }\end{array}$ & $\begin{array}{c}\text { For Each } \\
\text { Country } \\
\text { Separately }\end{array}$ \\
\hline R-squared & 0.769 & 0.795 & 0.654 & 0.678 \\
\hline Observations & 613,752 & 613,752 & 561,590 & 561,590 \\
\hline
\end{tabular}

The sample comprises firm-quarter observations from up to 35 (21) IFRS treatment (benchmark) countries over the 2001 to 2009 period. We report results for Bid-Ask Spreads and the Liquidity Factor as dependent variables. IFRS is a binary indicator variable for firm-quarters with mandatory IFRS reporting. For the analyses in this table we partition the IFRS observations into non-overlapping subsets using binary indicator variables. That is, we distinguish between voluntary and first-time mandatory IFRS adopters from EU countries that bundled IFRS adoption with substantive changes ( $\triangle$ ) in enforcement (vol_IFRS $S_{E U E N F}$ and man $I F R S_{E U E N F}$ ), voluntary and first-time mandatory IFRS adopters from EU countries with no such bundling (vol IFRS man_IFRS $\left.\bar{S}_{E U n n E E N F}\right)$, and firms from outside the EU $\left(I F R S_{n o n-E U}\right)$. We identify firms that voluntarily switched to IFRS reporting before 2005 based on Daske et al. (2011). Throughout the table, we include the full set of firm-level control variables and fixed effects in the models (see Models 2 and 4 in Table 3). To capture selection effects, we also include a binary indicator variable that takes on the value of ' 1 ' for voluntary IFRS adopters in the EU. We only report OLS coefficient estimates (t-statistics, clustered by country and calendar quarter) for the IFRS variables. We also report p-values from Wald tests assessing the statistical significance of the differences across select IFRS coefficients. ***,**, and * indicate statistical significance at the $1 \%, 5 \%$, and $10 \%$ levels (twotailed). 


\begin{tabular}{|c|c|c|c|c|c|c|}
\hline & \multicolumn{3}{|c|}{ Ln(Bid-Ask Spread) } & \multicolumn{3}{|c|}{ Ln(Liquidity Factor +1$)$} \\
\hline & \multirow{2}{*}{$\begin{array}{c}\Delta \text { Enforcement } \\
\text { in EU } \\
\text { Countries } \\
(1) \\
\end{array}$} & \multicolumn{2}{|c|}{$\begin{array}{c}\Delta \text { Enforcement Globally } \\
\text { (i.e., in IFRS \& } \\
\text { Non-IFRS Countries) }\end{array}$} & \multirow{2}{*}{$\begin{array}{c}\Delta \text { Enforcement } \\
\text { in EU } \\
\text { Countries } \\
(1)\end{array}$} & \multicolumn{2}{|c|}{$\begin{array}{c}\Delta \text { Enforcement Globally } \\
\text { (i.e., in IFRS \& } \\
\text { Non-IFRS Countries) }\end{array}$} \\
\hline & & $(2)$ & (3) & & $(2)$ & (3) \\
\hline \multicolumn{7}{|l|}{ Enforcement Changes (Not Bundled with IFRS): } \\
\hline$\Delta \mathrm{ENF}_{\mathrm{EU}}$ & $\begin{array}{l}-0.175 \\
(-1.50)\end{array}$ & - & - & $\begin{array}{l}-0.053^{*} \\
(-1.86)\end{array}$ & - & - \\
\hline$\Delta \mathrm{ENF}_{\text {IFRS }}$ & - & $\begin{array}{l}-0.363 * * * \\
(-3.72)\end{array}$ & $\begin{array}{l}-0.369 * * * \\
(-3.72)\end{array}$ & - & $\begin{array}{l}-0.165^{* * * *} \\
(-2.86)\end{array}$ & $\begin{array}{l}-0.172 * * * \\
(-2.74)\end{array}$ \\
\hline$\Delta \mathrm{ENF}_{\text {Japan }}$ & - & $\begin{array}{l}-0.113 * * \\
(-2.17)\end{array}$ & $\begin{array}{l}-0.113^{* *} \\
(-2.17)\end{array}$ & - & $\begin{array}{l}-0.163 * * * \\
(-7.48)\end{array}$ & $\begin{array}{l}-0.163^{* * * *} \\
(-7.48)\end{array}$ \\
\hline \multicolumn{7}{|l|}{ IFRS with Bundled $\Delta$ Enforcement (in EU): } \\
\hline $\mathrm{IFRS}_{\mathrm{EU} \_\mathrm{ENF}}$ & $\begin{array}{l}-0.441^{* * * *} \\
(-3.24)\end{array}$ & $\begin{array}{l}-0.452 * * * \\
(-3.30)\end{array}$ & $\begin{array}{l}-0.452 * * * \\
(-3.30)\end{array}$ & $\begin{array}{l}-0.263 * * * \\
(-4.73)\end{array}$ & $\begin{array}{l}-0.269 * * * \\
(-4.83)\end{array}$ & $\begin{array}{l}-0.269 * * * \\
(-4.81)\end{array}$ \\
\hline \multicolumn{7}{|l|}{ IFRS without Bundled $\Delta$ Enforcement: } \\
\hline $\mathrm{IFRS}_{\mathrm{EU} \_ \text {nonENF }}$ & $\begin{array}{l}-0.002 \\
(-0.02)\end{array}$ & - & - & $\begin{array}{c}-0.039 \\
(-0.63)\end{array}$ & - & - \\
\hline IFRS $_{\text {non-EU }}$ & $\begin{array}{c}0.088 \\
(1.15)\end{array}$ & - & - & $\begin{array}{c}0.018 \\
(0.47)\end{array}$ & - & - \\
\hline IFRS $_{\text {nonENF }}$ & - & $\begin{array}{r}0.003 \\
(0.03)\end{array}$ & - & - & $\begin{array}{c}-0.036 \\
(-0.58)\end{array}$ & - \\
\hline $\operatorname{IFRS}_{\text {nonENF1 }}(\Delta$ Enforcement but not bundled $)$ & - & - & $\begin{array}{c}0.026 \\
(0.33)\end{array}$ & - & - & $\begin{array}{c}-0.014 \\
(-0.21)\end{array}$ \\
\hline IFRS $_{\text {nonENF2 }}$ (No $\Delta$ Enforcement) & - & - & $\begin{array}{c}-0.001 \\
(-0.01)\end{array}$ & - & - & $\begin{array}{l}-0.040 \\
(-0.63)\end{array}$ \\
\hline Firm-level Control Variables & Yes & Yes & Yes & Yes & Yes & Yes \\
\hline Country \& Industry Fixed Effects & Yes & Yes & Yes & Yes & Yes & Yes \\
\hline Quarter-Year Fixed Effects & $\begin{array}{l}\text { Global, } \\
\text { IFRS \& EU } \\
\text { Countries }\end{array}$ & $\begin{array}{l}\text { Global, } \\
\text { IFRS \& EU } \\
\text { Countries }\end{array}$ & $\begin{array}{l}\text { Global, } \\
\text { IFRS \& EU } \\
\text { Countries }\end{array}$ & $\begin{array}{l}\text { Global, } \\
\text { IFRS \& EU } \\
\text { Countries }\end{array}$ & $\begin{array}{l}\text { Global, } \\
\text { IFRS \& EU } \\
\text { Countries }\end{array}$ & $\begin{array}{l}\text { Global, } \\
\text { IFRS \& EU } \\
\text { Countries }\end{array}$ \\
\hline R-squared & 0.769 & 0.770 & 0.770 & 0.654 & 0.656 & 0.656 \\
\hline Observations & 613,752 & 613,752 & 613,752 & 561,590 & 561,590 & 561,590 \\
\hline
\end{tabular}




\section{Table 6 (continued)}

The sample comprises firm-quarter observations from up to 35 (21) IFRS treatment (benchmark) countries over the 2001 to 2009 period. We report results for Bid-Ask Spreads and the Liquidity Factor as dependent variables. IFRS is a binary indicator variable for firm-quarters with mandatory IFRS reporting. $\triangle E N F$ is a binary indicator variable that takes on the value of ' 1 ' beginning in the calendar quarter following the first fiscal-year end after a substantive change ( $\Delta$ ) in enforcement took effect (e.g., the initiation of a proactive review process of financial statement information by the local supervisory authority). We identify the timing of substantive enforcement changes based on a survey of national regulators and audit firms and publicly available sources (see Table 1). For the analyses in this table we partition the IFRS and $\triangle E N F$ observations into subsets using binary indicator variables: (i) Focusing on enforcement changes in the EU, we distinguish between observations from EU countries that bundled IFRS adoption with enforcement changes (IFRS $\left.S_{E U} E N F\right)$, IFRS and, separately,

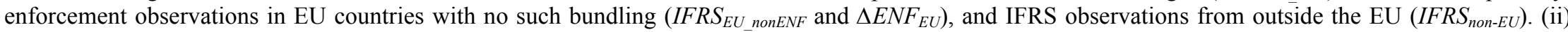
Focusing on enforcement changes globally, we distinguish between observations from countries that bundled IFRS adoption with enforcement changes (all in the EU, i.e., IFRS $S_{\left.E U_{-} E N\right)}$, IFRS and, separately, enforcement observations in IFRS countries with no such bundling (IFRS ${ }_{n o n E N F}$ and $\triangle E N F_{I F R S}$, and enforcement observations in countries that did not adopt IFRS, namely Japan $\left(\triangle E N F_{\text {Japan }}\right)$. (iii) We further split the $I F R S_{\text {nonENF }}$ coefficient into observations from countries that instituted a substantive enforcement change but did not bundle it with IFRS adoption (IFRS $\left.S_{n o n E N F I}\right)$ and observations from countries with no enforcement change over the sample period (IFRS $S_{\text {nonENF2 }}$ ). Throughout the table, we include the full set of firm-level control variables and fixed effects in the models (see Model 2 in Table 3), but only report OLS coefficient estimates (t-statistics, clustered by country and calendar quarter) for the IFRS and $\triangle E N F$ variables. $* * *, * *$, and $*$ indicate statistical significance at the $1 \%, 5 \%$, and $10 \%$ levels (two-tailed). 